\title{
Budgetary Interests and the Degree of Unbundling in Electricity Markets - An Empirical Analysis for OECD Countries*
}

\author{
Henrik Lindemann ${ }^{\bowtie}$
}

\author{
Discussion Paper No. 543 \\ ISSN 0949-9962 \\ January 2015
}

\begin{abstract}
The degree of liberalization in OECD electricity markets varies considerably across countries. Commonly explained by diverging economic performances, corruption levels or government ideologies, this paper suggest another potential reason for cross-national differences in market reforms: given the high financial dependence of regulatory actors on public funding both in the past and nowadays, we expect regulators to increasingly refrain from [foster] the implementation of liberalization steps, the more such measures reduce [raise] the revenues of a tax; this prevents [aims at realizing] substantial decreases [increases] in public revenues (being a major source of regulatory funds) and thus most likely also in the regulators' budgets. Estimation results substantiate these considerations for both the corporate income tax and (in cases of a high price elasticity of power demand) the VAT on electricity.
\end{abstract}

JEL-classification: L50, L94, L98

Keywords: $\quad$ Electricity Market Reform, Vertical Separation, Regulatory Authorities.

\footnotetext{
*I would like to thank Andreas Wagener, Patrick Puhani, Olaf Hübler, Stefan Schneck, Friederike von Haaren, Jörg Schwiebert and Konrad C. Schäfer as well as participants of the 9th EEM International Conference in Florence and the 31st USAEE/IAEE North American Conference in Austin for helpful suggestions and discussions. I am grateful to Christian Bjørnskov and Niklas Potrafke for providing me with the data of their ideology indices.

${ }^{\bowtie}$ Leibniz University of Hannover, School of Economics and Management, Koenigsworther Platz 1, 30167 Hannover, Germany, e-mail: lindemann@sopo.uni-hannover.de.
} 


\section{Introduction}

The degree of liberalization that has been realized in the electricity sector up to today varies considerably across countries (Conway and Nicoletti, 2006). Induced by an uneven pace of reform, empirical studies analyzing the reasons for policy changes offer several explanations for its divergence: economic performances (Drazen and Easterly, 2001; Pitlik and Wirth, 2003; Pitlik, 2008), the countries' levels of corruption (Emerson, 2006; van Koten and Ortman, 2008), or government ideologies (Pitlik, 2007; Potrafke, 2010).

We will elaborate on the related findings below, but advance another potential reason first: data suggest a relationship between taxation and electricity market reform. This is illustrated in Figures 1 and 2, respectively. To capture liberalization, we focus on the intensity of unbundling in the electricity sector, i.e. the degree of vertical separation between the industry's natural monopolies (transmission and distribution networks) and the potentially competitive stages of the value chain (generation, wholesale, and retail). Although somewhat restrictive, the particular importance of splitting these activities for a successful realization of fully competitive electricity markets (European Commission, 2007; European Union, 2009; Glachant and Léfêque, 2009) justifies this choice. In both scatterplots of Figures 1 and 2, the level of vertical separation is measured by an OECD indicator (OECD, 2011a). It ranges from 0 to 6 and decreases with stricter forms of unbundling ${ }^{1}$. The scope of taxation, in turn, is proxied by the rates of the corporate income tax rate (Figure 1) and the VAT rate on electricity (Figure 2); we thus cover two sources of public revenues that primarily affect one of the market sides each.

Data for 30 OECD countries ${ }^{2}$ and a 27-year period (1981-2007) are used to construct the first

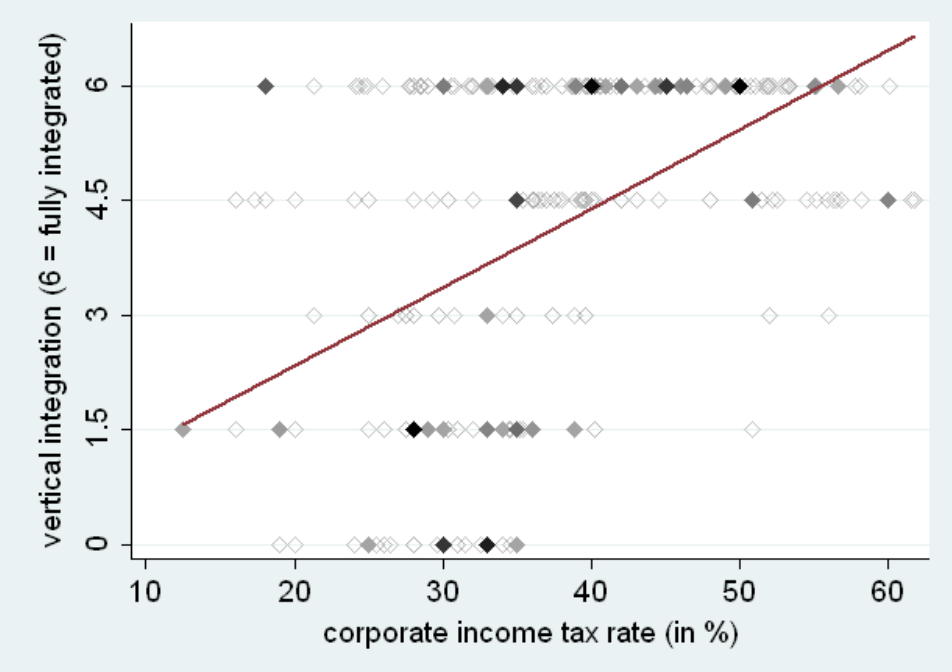

Figure 1: Corporate inCOME TAX AND Vertical integration IN ELECTRICITy MARKETS

\footnotetext{
${ }^{1}$ See Section 2.1 for a detailed description.

${ }^{2}$ The countries are AUS, AUT, BEL, CAN, CHE, CZE, DEU, DNK, ESP, FIN, FRA, GBR, GRC, HUN, ISL, IRL, ITA, JPN, KOR, LUX, MEX, NDL, NOR, NZL, POL, PRT, SVK, SWE, TUR and USA.
} 


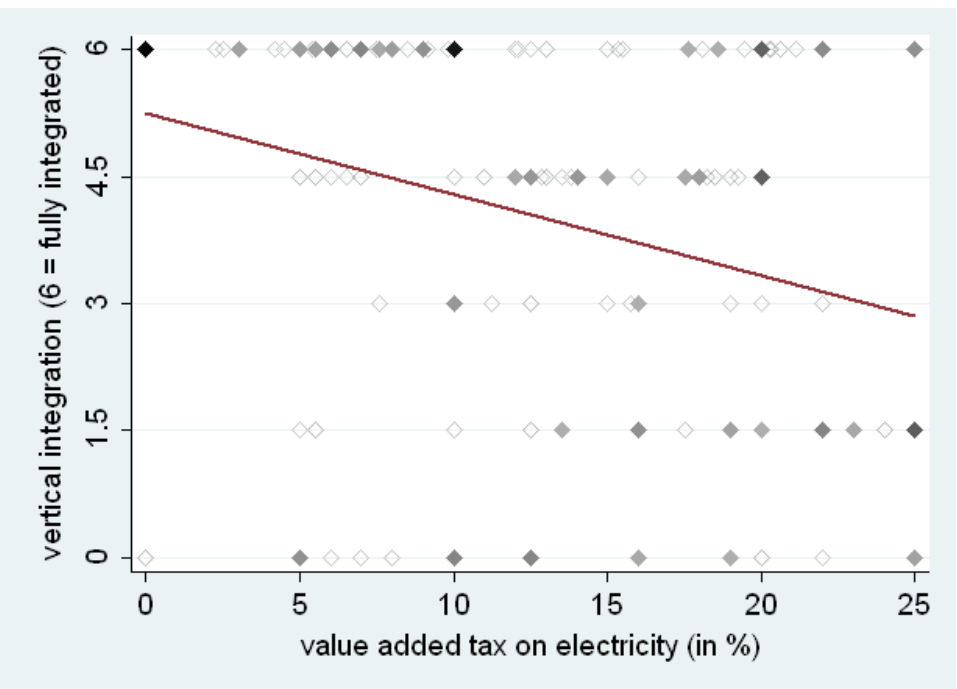

Figure 2: ElECTRICITY VAT AND VERTICAL INTEGRATION IN ELECTRICITY MARKETS

scatterplot. The brighter an observation point in the diagrams, the fewer identical observations it stands for; in case of less than five observations, the point is aditionally depicted as hollow. The fitted regression line included in the first plot has a positive slope, suggesting the level of unbundling to be lower in countries with higher corporate income tax rates.

The second scatterplot that compares the electricity VAT rate with the degree of vertical separation indicates an opposite relationship: for a sample comprising 19 OECD countries ${ }^{3}$ and the period from 1975 to 2007 , the fitted regression line rather hints at a liberalization-enhancing effect of higher levels of taxation.

With a negative [positive] relationship between tax rate and vertical separation being indicated by the graphs, our paper aims at testing whether these findings can stand sound empirical examination: drawing on the data used to create the scatterplots, we estimate the effect of a heavier taxation of corporate income and power consumption, respectively, on the scope of a country's electricity market reform by OLS. The outcomes are in line with both Figures 1 and 2 and suggest that the differences in the tax rates that have existed among OECD countries over the years could have triggered notable deviations in their unbundling regimes. These inferences hold when various combinations of controls are included in the regression to allow for other factors that potentially affect liberalization; and also a change of the estimation model from OLS to ordered logit, justifiable with the method used to calculate the vertical separation index, does not challenge the relationship depicted in the scatterplots.

This paper provides a possible explanation for the yet latent but apparently robust effect taxation seems to have on the structure of the power industry. In a nutshell, we suggest ministry

\footnotetext{
${ }^{3}$ The countries included are AUS, AUT, CAN, CHE, DEU, DNK, ESP, FIN, FRA, GBR, IRL, ITA, JPN, KOR, NDL, NOR, NZL, SVK and SWE. Compared to the sample used to construct the first scatterplot, the number of countries is reduced due to data restrictions.
} 
officials and authority members in charge of electricity regulation to strive for high government appropriations for their institutions and therefore to refrain from implementing [foster] unbundling measures that reduce [raise] the base of the corporate income tax and the electricity VAT, respectively; with a smaller [higher] tax base, tax yields are lower [higher], and thus also the funding for the ministry or regulatory agency is likely to decrease [increase]. As, for a given reduction [increase] in the tax base, the resulting decrease [increase] in tax revenues is higher, the higher the tax rate is, we expect a relationship to exist between how heavily corporate income and power consumption is taxed and the degree of vertical separation.

We discuss the different aspects of this potential explanation step by step. First, we illustrate why we assume regulatory actors to aim for high financial means for their institution. To this end, we split the period of electricity market regulation into two parts, differentiating between the early years where state ministries were responsible for industry oversight and the (ongoing) era of independent regulatory authorities. First concentrating on the early years of reform, we draw on the theory of bureaucracy (Niskanen, 1968, 1975; Migué and Bélanger, 1974; see also Downs, 1967, ch. IX; Rourke, 1984, ch. 4; Tullock et al., 2002, ch. 5) to substantiate our conjecture with respect to ministry employees: the theory claims that public officials strive to increase the power of the institution they work for and especially their remuneration to maximize their utility. To further corroborate our considerations, we present empirical studies indicating that an interest of bureaucrats in high funding for their offices or ministries might indeed exist.

Then, we provide two possible explanations for why we expect also members of regulatory authorities to aim for high government appropriations: on the one hand, it might be possible that regulators neglect their agency's official mission (Kay and Vickers, 1990) and pursue objectives similar to those ascribed to bureaucrats (Noll, 1989; Train, 1991, ch. I.1). On the other hand, the high financial resources authorities require to properly fulfill their mandate (OECD/IEA, 2001; Thatcher and Stone Sweet, 2002) might also induce regulators strictly focusing on their employers' official tasks to strive for budget increases. And as agencies are mainly publicly financed (OECD/IEA, 2001; CEER, 2005; Johannsen et al., 2005; Gilardi, 2008, ch. 8; Hanretty and Koop, 2009), any interest of a regulator in higher financial means induced by either of these motives basically amounts to being an interest in higher government appropriations.

Next, we briefly outline the literature that suggests that ministry and agency employees aiming for high institutional budgets also aim for high state budgets (Downs, 1967, ch. IX; Hood et al., 1984; Bowling et al., 2004) as the sizes of both budgets are interrelated (Blais and Dion, 1990; Wildavsky and Caiden, 2004, ch. 3) and discuss empirical studies supporting this view. Since it is reasonable to assume that the state budget increases with increasing tax yields, this would likewise imply an interest of such regulatory actors in high tax yields.

Based on these considerations, we finally provide a potential explanation for the liberalizationhampering effect of high corporate income tax rates. With an increasing unbundling intensity, 
the level of competition in the electricity industry is raised. This, in turn, reduces the companies' (previously anticompetitive) profits and thus the base of the corporate income tax: the tax can basically be seen as a tax on capital costs (Myles, 1995, ch. 8.2.2) and the remuneration of (equity) capital is usually higher, the higher the profits are. The loss in tax revenues that results from the tax base reduction, in turn, increases with the tax rate, so that regulatory actors striving for high government appropriations should especially refrain from implementing unbundling measures when corporate income is heavily taxed; in this case, the negative relationship between tax rate and the degree of unbundling our estimation results indicate would emerge.

The liberalization-enhancing effect of high electricity VAT rates our empirical findings furthermore suggest would then imply the base of the VAT to increase with higher levels of vertical separation. It can be shown, though, that this is only true when power demand is price elastic, which is rarely the case in reality. However, with the erroneousness of our notion that regulatory actors aiming for high budgets affect vertical separation or reverse causality being possible explanations for this contradiction, an additional estimation hints at another potential reason: when the unbundling intensity is regressed on both tax rates, the coefficient on the VAT rate becomes negligibly small and loses statistical significance, suggesting both the estimates indicating a reform-fostering effect to suffer from an omitted variable bias and ministry officials and regulators to focus on corporate taxation when they take their decisions.

The remainder of the paper is organized as follows: the next section describes the data and the estimation approach applied to empirically test the relationship between tax rates and unbundling level suggested by the scatterplots. Sections 3 and 4 report and discuss regression results and robustness checks. Section 5 then explains why we expect ministry officials and authority member responsible for regulation to be interested in high budgets for their institutions and and how this might induce an effect of tax rates on vertical separation. Section 6 concludes.

\section{Data and Methods}

\subsection{Main Variables and Estimation Method}

To capture the development of vertical separation in the electricity markets of different OECD countries, we draw on a sub-indicator of the ETCR (Energy, Transport and Communication Regulation) measure provided by the OECD (OECD, 2011a).

The ETCR indicator provides a summarizing index value for the overall effectiveness of regulation in seven non-manufacturing sectors by assessing their level of competition. It is obtained in several steps (Conway and Nicoletti, 2006): At first, two to four sub-indicators are calculated for the seven sectors (passenger air transport, telecom, electricity, gas, post, rail, and road freight). The number of sub-indicators differs depending on whether the issues covered by the five existing types (entry barriers, public ownership, vertical integration, market structure, 
and price controls) are relevant for the degree of competition in the respective sector or not. In case of an existing relevance, various questions that capture the situation prevailing in the respective sector with regard to the aspect the particular sub-indicator describes are answered on the basis of a wide range of data sources. Then, values between 0 and 6 are assigned to the answers, with higher values indicating less competitive environments. A weighted average of all answer values is calculated to obtain the sub-indicator. The values of the sub-indicators determined for a particular sector, in turn, are averaged in order to get the indicator for this industry. Finally, the simple average of all sector indicators yields the ETCR indicator which is available for 30 OECD countries and the period from 1975 to 2007.

Analyzing the relationship between taxation and the degree of separation in the electricity sector, we focus on the vertical integration sub-indicator for exactly this branch. Its value equals the average of the values assigned to the answers to the following two questions (answer values in parentheses) (Conway and Nicoletti, 2006):

1) What is the degree of vertical separation between the transmission and generation segments of the electricity industry?

- Separate companies. (0)

- Accounting separation. (3)

- Integrated. (6)

2) What is the overall degree of vertical integration in the electricity industry?

- Unbundled. (0)

- Mixed. (3)

- Integrated. (6)

Since the answer values are weighted equally, the sub-indicator increases in steps of 1.5 and can only take values $0,1.5,3,4.5$, and 6 .

We apply the combined central and sub-central corporate income tax rate as well as the rate of the VAT on electricity as main explanatory variables. The data on the corporate income tax rate are taken from OECD (2011b) and cover, as already outlined in the introduction, 30 OECD countries and the years from 1981 to 2007. The data on the electricity VAT rate cover 19 OECD countries and the period from 1975 to 2007; values were obtained from national tax authorities. Summary statistics for both tax rates as well as for the vertical integration sub-indicator and all controls used in the regressions can be found in Table 6 in the Appendix.

To test the relationship between the degree of unbundling and the rates of the corporate income tax and the electricity VAT, respectively, we estimate the equation 


$$
v i_{i t}=\alpha+\beta \cdot \operatorname{tax}_{i t}+\boldsymbol{\gamma} \cdot \boldsymbol{X}_{i t}+\delta \cdot c d u m_{i}+\theta \cdot y d u m_{t}+\epsilon_{i t} .
$$

The dependent variable $v i_{i t}$ denotes the degree of vertical separation, measured by the vertical integration sub-indicator value outlined above. Our main explanatory variable is the tax rate $\operatorname{tax}_{i t}$. Since we are interested in the influence of the corporate income as well as the value added tax, we run different estimations and switch the tax type each time. The vector $\boldsymbol{X}_{i t}$ contains further variables that might affect the intensity of unbundling; we describe these controls and substantiate their selection in the following section. The country and year dummies $c d u m_{i}$ and $y_{d u m_{t}}$, respectively, enable us to control for differences in country characteristics as well as for possible shocks and trends over time. Finally, $\epsilon_{i t}$ denotes the usual error term.

\subsection{Control Variables}

To allow for the effects factors other than the rates of the corporate income tax and the electricity VAT, respectively, might have on the level of vertical separation, we include the following control variables in our regressions:

- First, we add a country's total tax revenues as a control. As briefly outlined in the introduction, we suspect regulators to take account of what effect their decisions on the degree of unbundling have on tax yields, since they expect a shortfall in the receipts to be reflected in budget cuts for their agency. Such cuts, in turn, should carry rather little weight when high total tax revenues make high appropriations likely anyhow, and be painful for the authority when low tax yields already force the government to constrain the resources it allocates to public institutions. Regulatory measures that reduce tax receipts should accordingly be facilitated [hampered] by high [low] total tax revenues.

As soon as a change in regulation increases tax receipts, on the contrary, we expect the relationship between tax yields and the implementation of new rules to be exactly opposite: with overall tax revenues being high, generating additional tax payments via regulatory provisions should not be so urgent; available funds already allow the state to allocate considerable resources to the agency. Low tax yields, by contrast, should promote the modification of the rules: the financial leeway gained through the new regulatory regime might induce the government to increase the appropriations for the authority.

That is, we expect the coefficient on total tax revenues to be negative [positive] when unbundling measures lead to lower [higher] tax receipts. All these considerations make clear the influence of the type of unbundling on total tax revenues we assume to exist; to avoid the obvious endogeneity problem, we therefore include the control variable with a lag of one year (which reasonably implies that a state institution's funding depends on 
the country's financial situation in the previous period). Data are obtained from OECD (2010b).

- We furthermore control for a country's overall government debt (data are taken from OECD (2010b)). Since it is reasonable to assume that the funding for a regulatory institution increases with a decreasing national indebtedness, we expect all conclusions drawn for the tax revenues to hold the other way round: regulatory measures that lead to higher tax yields are probably implemented when debts are high; the additional public revenues generated by the change in the rules should result in higher appropriations for the (underfunded) agency. With a low government debt, on the contrary, altering the regulatory framework to increase tax receipts and thus the authority's resources is most likely unnecessary; the financial means allocated to the agency can be expected to be already high.

When regulatory provisions reduce tax revenues, a high indebtedness probably prevents their implementation, as the already low funding of the authority would otherwise be further reduced; high government appropriations in times of low debt, by contrast, should facilitate such regulations.

Accordingly, we expect a negative [positive] estimate on total government debt when a higher degree of vertical separation increases [lowers] tax receipts. To avoid reverse causality issues, also this control is included in the regressions with a lag of one period.

- Next, we extend the estimation to allow for the economic performance of a country in the previous year. In general, each economic reform creates a group of gainers and a group of losers (Drazen and Grilli, 1993; Krueger, 1993; Rodrik, 1996; Bean, 1998), and while those gaining usually support the policy change, the market actors benefiting from the pre-reform situation are expected to often fiercely oppose it (Drazen and Grilli, 1993; Rodrik, 1996). The so-called "crisis hypothesis" therefore claims that a troubled economy is a prerequisite for reform: the associated detriments will force politicians to implement corrective measures, ensure the political support necessary for these changes (Drazen and Grilli, 1993; Krueger, 1993; Rodrik, 1996; Drazen and Easterly, 2001) and can - in case of a deep crisis which affects almost everybody - even reduce the resistance of beneficiaries of the old status quo (Rodrik, 1996).

Theoretical (Drazen and Grilli, 1993) and empirical (Drazen and Easterly, 2001; Pitlik and Wirth, 2003) findings support the hypothesis with respect to inflation and identify considerable currency devaluations to be a trigger for reform. However, with respect to economic growth, empiricial results are less straightforward: Pitlik and Wirth (2003) show that a country's liberalization efforts are only higher in the wake of a deep crisis; after a medium growth crisis, on the contrary, the willingness to reform is even weaker than in 
the aftermath of an upswing or a boom ${ }^{4}$. Pitlik's (2008) study reveals that the positive effect of an economic downturn on the scope of liberalization predicted by the hypothesis can only be observed in democracies or when a country's political system includes a high number of veto players; for autocratic regimes, his findings suggest reforms to be introduced only after periods of growth (with results holding independently of the severity of the crisis). And Drazen and Easterly's (2001) and Pitlik's (2007) results hint at a liberalization-enhancing effect of economic downturns, but they (often) do not reach statistical significance (particularly relevant in our case is that Pitlik (2007) cannot identify any statistically significant impact of growth crises on the design of regulatory regimes).

We decided to check for a possible effect of a country's economic problems on liberalization by including the growth rate of the real GDP (calculated on the basis of real GDP data obtained from the World Bank (2011)) lagged by one year as a control variable, thus neglecting the potentially existing relevance of the crisis's severity Pitlik and Wirth's (2003) findings suggest. Based on the outlined results (and since our OECD sample does not include any autocracies), we therefore expect the coefficients on the growth rate to be positive (albeit not necessarily statistically significant). With the inflation rates found to trigger reform being exceptionally high ${ }^{5}$, we furthermore refrained from adding a control capturing currency devaluation.

- In addition, we control for the energy intensity in the sample countries by including the primary energy supply (measured in tonnes of oil equivalent) per GDP unit as a proxy (OECD, 2010a). Since high needs of primary energy caused by, e.g., extreme weather conditions or energy-intensive industries strengthen the desire for cheap electricity, we expect negative coefficients to occur.

\footnotetext{
${ }^{4}$ Pitlik and Wirth (2003) define a medium and a deep growth crisis as follows: a value of 1 is assigned to each year with a non-positive growth rate being higher than $-1 \%$; years with a rate equal to or smaller than $-1 \%$ recieve a value of 2 . A five year period with a sum between 3 and 5 is then classified as a medium growth crisis, a five year period with an overall value greater than 5 constitutes a deep crisis. Pitlik and Wirth's (2003) result that medium growth crises lead to lower reform efforts than upswings and booms substantiates Bean's (1998) conjecture that, unlike as claimed by the "crisis hypothesis", changes are induced by good economic performances, as they facilitate the compensation of beneficiaries of the status quo opposing reform.

${ }^{5}$ As in the case of growth (see footnote 4), Pitlik and Wirth (2003) distinguish between a medium and a deep crisis also with respect to inflation, defining the two types as follows: a value of 1 is assigned to each year with an inflation rate being higher than or equal to $10 \%$ and smaller than $40 \%$, years with an inflation rate equal to $40 \%$ or smaller than $100 \%$ receive a value of 2 ; finally, years in which the inflation rate exceeded $100 \%$ get a value of 3 . Then, a five year period with a sum between 2 and 10 is classified as a medium inflation crisis, a five year period with a total value greater than 10 constitutes a deep crisis. Drazen and Easterly (2001), splitting their sample into groups according to the sample countries' inflation rate, find effects of currency devaluation on reform to exist only for the groups with a median annual inflation rate of $68 \%$ or of at least $100 \%$, respectively (depending on whether they apply an accurate or a rough classification).
} 
- We also control for the level of corruption prevailing in the public sector. Venal bureaucrats in charge of regulation are expected to implement provisions or, conversely, to refrain from their implementation (Tanzi, 1994; Ades and Di Tella, 1997a) to ensure persistent high profits for the (usually few) firms active in the regulated industry. This malfeasance obviously reinforces existing market imperfections (Tanzi, 1994), since excessive earnings can only be generated in non-competitive environments, but, above all, it allows corrupt officials to demand high bribes for themselves (Tanzi, 1994; Ades and Di Tella, 1997a, 1997b, 1999): companies benefiting from the suppression of competition possess both the financial means and the willingness to pay large kickbacks in order to preserve their advantageous situation (Mauro, 1996; Ades and Di Tella, 1997a; Treisman, 2000). Bureaucrats aiming at a share in the incumbents' rents are therefore suspected of keeping them as high as possible by shielding oligopolistic markets from new entrants (Ades and Di Tella, 1997a; Treisman, 2000).

Both theoretical and empirical research hints at the existence of such a malfeasant behavior by corrupt officials: Emerson's (2006) model shows that it is optimal for a venal civil servant regulating a market supplied by a Cournot oligopoly with a competitive fringe to constrain the number of Cournot competitors; this allows him to ask for higher bribes. Estimations included in the paper as well furthermore substantiate the conjectured competition-hampering effect of high levels of corruption. Van Koten and Ortman (2008), analyzing the relationship between corruption and the degree of transmission network unbundling in the electricity sectors of the EU-15 and ten further member states that acceded to the EU in 2004, find venal public officials and politicians to be associated with less stringent separation levels in EU-15 states, but to higher ones in the ten accession states. However, the authors suspect the converse results for the new member states to be induced by fraudulent reports on their true unbundling situation especially in the years before 2004, because a failure in implementing the stipulated degree of separation would have jeopardized their accession to the EU. Since compared to restructuring the whole electricity sector to meet EU requirements misreporting was particularly easy to realize in very corrupt countries, it is conjectured that in fact the correlation between the degree of unbundling and the CPI was the same in EU-15 and accession states.

To allow for a potential effect of corruption on vertical separation, we include the Corruption Perceptions Index (CPI) compiled by Transparency International (2012; see Lambsdorff (2006) for details) as a control variable; it ranges from 0 to 10 and increases as the perceived susceptibility to bribery in a country's public sector decreases. Based on the literature suggesting that more corrupt countries tend to procrastinate on state interferences fostering competition, we therefore expect a negative coefficient to occur. 
- Our next control variable captures the government's ideology. Right-wing politicians are usually seen as advocates of only minimal state interventions who promote deregulation whenever possible and prefer the free market to rule. Left-wing politicians, on the contrary, are expected to be rather interested in taming the market and therefore in comprehensive regulatory measures (Benoit and Laver, 2006, ch. 6). This notion is substantiated by Pitlik's (2007) and Potrafke's (2010) estimation results: both find the level of deregulation to be higher in countries where right-wing governments are in power.

We check for the suggested liberalization-enhancing effect of right-wing cabinets by adding Potrafke's (2009) ideology index as a control. It takes values between 1 and 5 and increases as the share of seats left-wing parties hold in parliament and government grows; consequently, a positive coefficient on the ideology measure is likely to arise.

Apart from being an indicator of government ideology, the index might also be seen as a proxy for the political orientation of those directly responsible for regulation. On the one hand, it happens quite often that after a change of government leading positions in ministries are restaffed by civil servants that are close to cabinet members. In the period where electricity markets were regulated by ministry officials, a congruence of government ideology and the political orientation of senior civil servants hence most likely existed, implying the index to properly reflect the ideology of the officials supervising the sector as well. On the other hand, the workforce of today's regulatory authorities is usually formed by representatives of all relevant (political) parties (Thatcher, 2002a). If one now reasonably assumes that the number of representatives increases in the parties' strength, the political views prevailing among agency members should be appropriately captured by an ideology index that describes the distribution of seats in both government and parliament.

- Finally, we take account of a potential EU membership effect. The European Union has been very active and ambitious in the area of regulatory policy-making; as a consequence, the resulting legislation member states are obliged to implement frequently exceeds by far the exclusively national provisions both in terms of quantity and quality (Majone, 1996). This is also true for energy policy, where the liberalization of European energy markets as well as the realization of a single EU market is the major objective of the Commission: three legislative packages for an internal EU gas and electricity market have therefore been adopted until today which include as many electricity directives (European Communities, 1996; European Union, 2003, 2009). They require, inter alia, the implementation of increasingly stronger forms of unbundling in the member states, suggesting higher degrees of vertical seperation in EU compared to non-EU OECD countries surveyed in our sample. Beyond that, research emphasizes the pressure European institutions have put on member states in the recent past to prompt them to establish independent regulators and vest 
them with wide-ranging authorities (Döhler, 2002; see European Union, 2003, 2009 for the legal provisions). Given that such agencies are rated as a driving force for a profound liberalization process (OECD/IEA, 2001), this requirement should further reinforce the presumably higher reform efforts in EU countries ${ }^{6}$.

The conjectured relationship is anything but uncontroversial, though: a comparative study between the EU-15 except for Luxembourg and groups of 16 South American and eight developed democratic countries, respectively, concludes that in the electricity sector reliable evidence for a liberalization-enhancing effect of an EU membership is lacking (Levi-Faur, 2004). It shows that the steps of reform undertaken to promote competition in both wholesale and retail markets were more comprehensive in the European Union than in South America; but at the same time, it reveals that, compared to the economically more similar democratic countries, the liberalization efforts of EU member states were lower with respect to retail activities and only higher in wholesale markets.

To capture a potential effect of an EU membership in our regressions we add a dummy control variable that is constructed on the basis of EU accession dates (taken from European Union (2011)). Levi-Faur's (2004) findings challenging the liberalization-enhancing role of the EU notwithstanding and based on the non-empirical literature discussed above, we expect stricter forms of unbundling to be suggested by the estimation results for member states (i.e., a negative dummy coefficient); however, it appears questionable whether the estimate can reach statistical significance.

\section{Estimation Results: Corporate Income Tax}

\subsection{Basic Results}

We start with analyzing the relationship between the corporate income tax rate and vertical separation. Table 1 illustrates the regression results from OLS estimations. Independent of the model specification, the tax rate coefficient shows a positive and statistically highly significant sign; the conjecture of a liberalization-hampering effect of high tax rates suggested by Figure 1 is thus further substantiated. If the bivariate model reported in the first column is neglected at this point, the coefficient size lies between 0.03 and 0.06 ; it reaches its minimum when all controls are included in the regression (and the associated data restrictions moreover notably reduce the number of observations). The most comprehensive estimation model thus suggests

\footnotetext{
${ }^{6}$ The cooperation between regulators initiated by the Commission (Thatcher, 2002a) might even amplify the conjectured effect: although his a sample of 16 European independent authorities does not include electricity regulators, it does not seem erroneous to assume that Maggetti's (2007) findings suggesting a reduction of the regulatees' competition-hampering interference in an agency's day-to-day operation when the authority is part of a network group also holds for energy markets.
} 
Table 1: OLS Regression Results

\begin{tabular}{|c|c|c|c|c|c|c|c|}
\hline & (1) & $(2)$ & $(3)$ & (4) & $(5)$ & (6) & (7) \\
\hline \multirow[t]{2}{*}{ CITrate } & $.1030^{* * *}$ & $.0546^{* * *}$ & $.0538^{* * *}$ & $.0592^{* * *}$ & $.0573^{* * *}$ & $.0351^{* * *}$ & $.0338^{* * *}$ \\
\hline & $(0.008)$ & $(0.009)$ & $(0.009)$ & $(0.009)$ & $(0.010)$ & $(0.009)$ & $(0.009)$ \\
\hline \multirow[t]{2}{*}{ totaltaxrev $t-1$} & & $-5.1 e-09$ & $-3.1 e-09$ & $-2.2 \mathrm{e}-09$ & $-1.8 \mathrm{e}-09$ & $1.3 e-07$ & $1.6 \mathrm{e}-07$ \\
\hline & & $(0.000)$ & $(0.000)$ & $(0.000)$ & $(0.000)$ & $(0.000)$ & $(0.000)$ \\
\hline \multirow[t]{2}{*}{ totalgovdebt $_{t-1}$} & & $4.3 \mathrm{e}-07^{* * *}$ & $4.2 \mathrm{e}-07^{* * *}$ & $4.1 \mathrm{e}-07^{* * *}$ & $4.0 \mathrm{e}-07^{* * *}$ & $3.8 \mathrm{e}-07^{* * *}$ & $3.5 \mathrm{e}-07^{* * *}$ \\
\hline & & $(0.000)$ & $(0.000)$ & $(0.000)$ & $(0.000)$ & $(0.000)$ & $(0.000)$ \\
\hline \multirow[t]{2}{*}{ GDPgrowth $_{t-1}$} & & & -.0304 & $-.0410^{*}$ & $-.0481^{*}$ & -.0324 & -.0217 \\
\hline & & & $(0.024)$ & $(0.024)$ & $(0.026)$ & $(0.028)$ & $(0.029)$ \\
\hline \multirow[t]{2}{*}{ energysupGDP } & & & & $-7.675^{* * *}$ & $-6.568^{* *}$ & $-14.12^{* * *}$ & $-12.71^{* * *}$ \\
\hline & & & & $(2.776)$ & $(3.172)$ & $(3.900)$ & $(3.969)$ \\
\hline \multirow[t]{2}{*}{ TIcor } & & & & & -.0648 & $-.3052^{* * *}$ & $-.2873^{* * *}$ \\
\hline & & & & & $(0.095)$ & $(0.093)$ & $(0.091)$ \\
\hline \multirow[t]{2}{*}{ ideopotr } & & & & & & $.2145^{* * *}$ & $.2143^{* * *}$ \\
\hline & & & & & & $(0.061)$ & $(0.061)$ \\
\hline \multirow[t]{2}{*}{ EUdum } & & & & & & & -.3916 \\
\hline & & & & & & & $(0.276)$ \\
\hline \multirow[t]{2}{*}{ constant } & .2781 & $2.383^{* * *}$ & $2.526^{* * *}$ & $4.172^{* * *}$ & $4.464^{* * *}$ & $8.872^{* * *}$ & $8.303^{* * *}$ \\
\hline & $(0.326)$ & $(0.593)$ & $(0.600)$ & $(0.889)$ & $(1.022)$ & $(1.033)$ & $(1.106)$ \\
\hline country dummies & no & yes & yes & yes & yes & yes & yes \\
\hline year dummies & no & yes & yes & yes & yes & yes & yes \\
\hline$R^{2}$ & .2102 & .7877 & .7883 & .7912 & .7906 & .8265 & .8275 \\
\hline$N$ & 682 & 588 & 588 & 588 & 557 & 470 & 470 \\
\hline
\end{tabular}

the vertical integration index to grow by about 0.35 units when the corporate income tax rate is increased by ten percentage points.

Apart from the tax rate also several control variables are statistically significant: first, all coefficients on the lagged government debt reach significance at the $1 \%$ level and hint at lower degrees of vertical separation in countries with high national deficits. Given that estimation results at the same time suggest only limited liberalization efforts in cases of higher corporate income tax rates, this is in line with our considerations briefly outlined in the introduction and Section 2.2, respectively: an increase in unbundling seems to reduce the tax base for and thus also the tax yields from corporate taxation; this results in a hesitant attitude towards separation measures especially when existing debts are already high. The size of the estimated effect, though, is virtually zero, indicating that decisions on the implementation of unbundling measures are basically taken independently of the level of indebtedness in the previous year.

The negative coefficient on the lagged GDP growth reaches statistical significance only in columns (4) and (5) and there also just at the $10 \%$ level. The estimates in these cases rather challenge the "crisis hypothesis": they hint at stricter forms of unbundling after a high GDP growth in the previous year, which could only be reconciled with previous findings at least partially substantiating the hypothesis when the economic downturns covered by our sample would 
be classified as what Pitlik and Wirth (2003) call a "medium crisis"; the U-shaped relationship between growth and the scope of reform they identify suggests that liberalization efforts in the wake of such minor economic turbulences are lower than those following times without economic problems. However, given that the size of the significant coefficients is rather small (to reduce the vertical integration measure by half a unit, the growth rate has to increase by more than ten percentage points) and, above all, statistical significance is entirely lost when further controls are added in the last two columns, overall results seem to indicate that the unbundling level in our sample countries is not affected by their growth performance.

Energy-intensive production processes, on the contrary, are suggested to foster reform significantly: the respective coefficients are all negative and - except in column (5), where the estimate can only reach the $5 \%$ significance level - statistically highly significant. The size of the effect is furthermore suggested to be considerable: the coefficient provided by the most comprehensive regression model indicates that an increase in the amount of primary energy required to produce 1000 US $\$$ of GDP by 0.1 tonnes of oil equivalent decreases the vertical integration measure by more than 1.25 .

Estimation results likewise hint at higher degrees of unbundling in countries with officials less susceptible to bribery: the coefficients on the corruption index are negative and reach high statistical significance in columns (6) and (7). The significant estimates indicate an integration index reduction of approximately 0.3 for each one-unit increase in the CPI.

The conjectured relationship between government ideology and vertical separation is substantiated by the regression outcome as well: as expected, the highly significant control variables suggest lagging reforms in countries governed by left-wing parties. The size of the estimates imply that a change from a right-wing to a left-wing cabinet (leading to an ideology index increase from 1 to 5) ceteris paribus raises the unbundling measure by about 0.85 .

Finally, the results suggest than the lagged tax revenue and a country's membership in the EU do not have an effect on the degree of unbundling as the respective coefficients cannot reach statistical significance.

\subsection{Robustness Checks}

We check the robustness of our findings in four different ways: first, we change the estimation method and use ordered logit regression instead of OLS. Then, we substitute several control variables included in the basic estimation with alternative, but closely related measures and rerun the OLS regression. Afterwards, both modifications are combined and an ordered logit model with the new set of controls is estimated. Finally, we re-estimate the most comprehensive basic regression and all robustness checks with both the energy intensity proxy and the corruption index being lagged by one year to ensure that our results do not suffer from endogeneity problems these two controls might cause when they are not lagged. 


\subsubsection{Ordered Logit Regression}

Calculated as the mean of the two answer values assigned according to the level of separation between generation and transmission and within the electricity sector, respectively, the vertical integration sub-indicator we employ as dependent variable requires the scales of the two questions it is composed of to be cardinal. It might be argued, though, that the assumption of cardinality inherent in the way the measure is constructed is at least problematic: according to the literature discussing the effects of unbundling (see, e.g., OECD, 2001; European Commission, 2007; Pollitt, 2008), Ownership Unbundling, i.e. the complete separation of the monopolistic networks from electricity generation and retail, is essential to realize full competition in the non-network activities; only this strict form of unbundling ensures that incentives of network monopolists to discriminate against independent rivals of the affiliated generators and retailers are completely eliminated. That is, with reductions in the sub-indicator value supposed to reflect respective increases in the level of electricity sector competition, regulations requesting a separation of the grids by ownership should result in a considerably higher decrease of the integration measure than other, less drastic interferences. This, however, is not the case: sub-indicator values imply that, e.g., regulatory provisions for a completely vertically integrated industry that demand accounting separation between generation and transmission and entail the coexistence of unbundled and integrated companies (leading to a sub-indicator decrease from 6 to 3) would have the same effect on competition as a subsequent reform step compelling ownership separation between natural monopolies and all other stages of the value chain throughout the sector (resulting in another 3-unit drop to 0). The calculation method of the sub-indicator assuming cardinality notwithstanding, we therefore suggest an alternative and simpler interpretation of changes in the integration measure value: they can be construed as solely reflecting the completion of a liberalization step. With each of them reducing the measure by 1.5 , we get a simple ordinal scale, not rating the intensity of the different regulatory interventions.

This allows us to test the robustness of our OLS results by estimating the effect of higher tax rates on liberalization within the framework of an ordered logit model. The ordered logit model can be applied in case of discrete ordinal dependent variables that reflect a ranking of the possible outcomes, but do not allow for comparing the differences between response categories (Wooldridge, 2002, ch. 15.10.1). The basis of the approach is the latent regression

$$
v i_{i t}^{*}=\boldsymbol{\beta} \cdot \boldsymbol{Z}_{i t}+\eta_{i t},
$$

where $\boldsymbol{Z}_{\boldsymbol{i t}}$ includes the tax rate $\operatorname{tax}_{i t}$, the controls composing $\boldsymbol{X}_{\boldsymbol{i}}$ in the OLS regressions and country $\left(c_{d u m_{i}}\right)$ and year dummies $\left(y d u m_{t}\right)$, but no constant; the error term $\eta_{i t}$ is logistically

distributed with distribution function $\Lambda\left(\eta_{i t}\right)=\frac{1}{1+e^{-\eta_{i t}}}$. With a national electricity sector's 
actual level of unbundling at a certain year, $v i_{i t}^{*}$, being a latent variable, we can draw on the sub-indicator values $v i_{i t} \in\{0,1.5,3,4.5,6\}$ to approximate the degree of separation. There exist five unknown cut points $\kappa_{j}$ with $j=1, \ldots, 5$ and $-\infty=\kappa_{0}<\ldots<\kappa_{j-1}<\kappa_{j}<\ldots<\kappa_{5}=\infty$, so that

$$
y_{i t}=v i_{i t} \quad \text { if } \quad \kappa_{j-1}<y_{i t}^{*} \leq \kappa_{j}
$$

yielding response probabilities

$$
\operatorname{Pr}\left(y_{i t}=v i_{i t} \mid \boldsymbol{Z}_{\boldsymbol{i t}}\right)=\operatorname{Pr}\left(\kappa_{j-1}<y_{i t}^{*} \leq \kappa_{j} \mid \boldsymbol{Z}_{\boldsymbol{i t}}\right)=\Lambda\left(\kappa_{j}-\boldsymbol{\beta} \cdot \boldsymbol{Z}_{\boldsymbol{i t}}\right)-\Lambda\left(\kappa_{j-1}-\boldsymbol{\beta} \cdot \boldsymbol{Z}_{\boldsymbol{i t}}\right) .
$$

These are then used to estimate both the coefficients $\boldsymbol{\beta}$ and the threshold values $\kappa_{j}$ by the maximum likelihood method (Wooldridge, 2002, ch. 15.10.1; Cameron and Trivedi, 2005, ch. 15.9.1).

The estimates of the ordered logit regression are reported in the first column of Table 2 . However, positive [negative] coefficients solely illustrate that the probability of the dependent variable to take on a value of 6 increases [decreases] and its likelihood to be 0 decreases [increases]; conclusions about the three intermediate scores or effect sizes, on the contrary, cannot be drawn (Wooldridge, 2002, ch. 15.10.1). We can thus only state that the negative relationship between corporate income tax rate and unbundling level suggested earlier by the OLS results is further corroborated by the ordered logit findings for complete integration and full separation: the positive coefficient is statistically significant at the $5 \%$ level.

Likewise, also the liberalization-enhancing effects of energy-intensive production processes, low levels of corruption and right-wing governments suggested by the most comprehensive basic OLS regression (see column (7) of Table 1) are substantiated with respect to the lowest and the highest intensity of unbundling: the coefficients on both the energy intensity proxy and the corruption measure are negative, the estimate on the ideology index is positive, and all three coefficients are statistically highly significant.

Unlike the OLS estimation, the ordered logit regression furthermore indicates a higher [lower] probability for the electricity industry to be entirely unbundled [integrated] in EU member states: the coefficient on the EU dummy is negative and reaches statistical significance at the $5 \%$ level. Moreover, the ordered logit results suggest the power sector to be more often fully separated [integrated] when tax revenues are low [high] and government debt is high [low] (with the positive estimate on tax yields and the negative one on debt being significant at the $1 \%$ and the $5 \%$ level, respectively), which is at odds with our original considerations: as we assume the base of the 
Table 2: Robustness Checks

\begin{tabular}{|c|c|c|c|}
\hline & (1) & (2) & (3) \\
\hline \multirow[t]{2}{*}{ CITrate } & $.0580^{* *}$ & $.0330^{* * *}$ & $.0596^{*}$ \\
\hline & $(0.028)$ & $(0.011)$ & $(0.033)$ \\
\hline \multirow[t]{2}{*}{$\operatorname{totaltaxrev}_{t-1}$} & $4.6 \mathrm{e}-06^{* * *}$ & & \\
\hline & $(0.000)$ & & \\
\hline \multirow[t]{2}{*}{$\operatorname{taxrevGDP}_{t-1}$} & & .0050 & -.0481 \\
\hline & & $(0.033)$ & $(0.086)$ \\
\hline \multirow[t]{2}{*}{ totalgovdebt $_{t-1}$} & $-2.0 \mathrm{e}-06^{* *}$ & & \\
\hline & $(0.000)$ & & \\
\hline \multirow[t]{2}{*}{ govdebtGDP $_{t-1}$} & & $.0078^{*}$ & -.0011 \\
\hline & & $(0.004)$ & $(0.019)$ \\
\hline \multirow[t]{2}{*}{ GDPgrowth $_{t-1}$} & -.0362 & & \\
\hline & $(0.090)$ & & \\
\hline \multirow[t]{2}{*}{ GDPcapgrowth $_{t-1}$} & & -.0084 & -.0098 \\
\hline & & $(0.029)$ & $(0.074)$ \\
\hline \multirow[t]{2}{*}{ energysupGDP } & $-64.94^{* * *}$ & & \\
\hline & $(12.62)$ & & \\
\hline \multirow[t]{2}{*}{ energysupcap } & & $-.4328^{*}$ & -.8313 \\
\hline & & $(0.239)$ & $(0.789)$ \\
\hline \multirow[t]{2}{*}{ TIcor } & $-1.018^{* * *}$ & $-.1995^{* *}$ & $-.4415^{*}$ \\
\hline & $(0.288)$ & $(0.088)$ & $(0.238)$ \\
\hline \multirow[t]{2}{*}{ ideopotr } & $.6124^{* * *}$ & & \\
\hline & $(0.171)$ & & \\
\hline \multirow[t]{2}{*}{ ideobjor } & & -.2662 & -.2676 \\
\hline & & $(0.198)$ & $(0.681)$ \\
\hline \multirow[t]{2}{*}{ EUdum } & $-1.902^{* *}$ & $-1.004^{* * *}$ & $-1.877^{* *}$ \\
\hline & $(0.799)$ & $(0.285)$ & $(0.761)$ \\
\hline \multirow[t]{2}{*}{ constant } & & $6.835^{* * *}$ & \\
\hline & & $(1.439)$ & \\
\hline country dummies & yes & yes & yes \\
\hline year dummies & yes & yes & yes \\
\hline$R^{2}$ & & .7922 & \\
\hline Pseudo $-R^{2}$ & .6456 & & .5850 \\
\hline$N$ & 470 & 438 & 438 \\
\hline
\end{tabular}

Note: Columns (1) and (3) show estimation results of ordered logit regressions, column (2) those of a standard linear OLS estimation. Dependent variable is the vertical integration sub-indicator for the electricity sector as described in Conway and Nicoletti (2006). Robust standard errors in parentheses. $* * * / * * / *$ denotes statistical significance at the $1 \% / 5 \% / 10 \%$ level.

corporate income tax to decrease with stricter forms of unbundling due to the positive tax rate coefficient, opposite signs of the estimates would have been in line with our expectations. A possible explanation might be as follows: regulatory decision makers focused on high tax yields 
Table 2A: Changes in Expected VI Subindicator Values

\begin{tabular}{lllllll}
\hline & \multicolumn{6}{c}{ corporate income tax rate base level $(\overline{\text { CITrate }})$} \\
& $10 \%$ & $20 \%$ & $30 \%$ & $40 \%$ & $50 \%$ & $60 \%$ \\
\hline$\Delta E(v i)$ & .0171 & .0169 & .0165 & .0158 & .0150 & .0140 \\
\hline \hline
\end{tabular}

Note: Table 2A reports changes in the conditional expected values of the vertical integration sub-indicator for the electricity sector induced by a one percentage point increase in the corporate income tax rate, starting from the respective base level $\overline{\text { CITrate. }}$ Conditional expected values are calculated by means of the average predicted probabilities based on the ordered logit estimates reported in column (1) of Table 2.

might rather apply both total tax revenues and government debt as indicators of a country's economic performance than the GDP growth rate (which is why its coefficient is statistically insignificant); high tax yield would then indicate an upswing or a boom, while high government debt would hint at a downturn or a depression. With the energy sector rated as being essential for the economic development of a country (Schneider and Jäger, 2003; Domanico, 2007; Karan and Kazdağli, 2011), signs of an economic crisis (i.e., a high indebtedness) might then induce regulators to foster competition by unbundling to reduce power prices, while high tax revenues might prompt them to slow down reform.

To finally assess the quantitative relationship between corporate income tax rate and unbundling level within the framework of the ordered logit model, we follow the procedure described

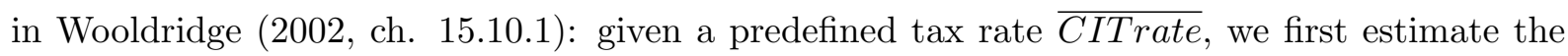
average predicted probabilities for each value the vertical integration index can take. Based on these estimates, we then calculate the conditional expected value of the unbundling measure

$$
E\left(v i \mid \overline{\text { CITrate }}, \boldsymbol{Z}^{-}\right)=\sum_{s} s \cdot P\left(v i=s \mid \overline{\text { CITrate }}, Z^{-}\right),
$$

with $\boldsymbol{Z}^{-}$comprising all controls included in $\boldsymbol{Z}$ apart from the tax rate.

After the same is done for a tax rate exceeding $\overline{\text { CITrate }}$ by one percentage point, $\overline{\text { CITrate }^{+}}$, we compute the difference in the conditional expected values

$$
\Delta E(v i)=E\left(v i \mid \overline{\text { ITrate }^{+}}, \boldsymbol{Z}^{-}\right)-E\left(v i \mid \overline{\text { CITrate }}, \boldsymbol{Z}^{-}\right) .
$$

$\Delta E(v i)$ is then comparable to the OLS coefficient on the corporate income tax rate reported in the last column of Table 1.

Table $2 \mathrm{~A}$ reports the $\Delta E(v i)$-values for six different tax rate base levels that cover the range of rates observed in our sample (see Table 6). All of them confirm the liberalization-hampering 
effect of higher corporate income tax rates indicated by the positive ordered logit estimate, but at the same time they hint at a more modest impact than their OLS counterpart: decreasing with a higher $\overline{C I T r a t e}$, the figures are about one half to three fifth lower than the OLS estimate, suggesting that a one percentage point increase in the tax rate raises the conditional expected value of the unbundling index by only 0.017 to 0.014 units.

\subsubsection{Alternative Controls}

The modified set of controls we employ to further check the robustness of our results is composed as follows: we replace the lagged total tax revenue as well as the lagged total government debt with the lagged tax revenue and the lagged government debt as percentages of GDP (data are obtained from OECD (2010a)). Furthermore, the lagged GDP per capita growth rate (calculated on the basis of GDP per capita data provided by World Bank (2011)) is used instead of the lagged GDP growth rate. The primary energy supply per capita, an alternative measure of energy intensity (OECD, 2010b), is substituted for the primary energy supply per GDP unit. Finally, we replace Potrafke's (2009) ideology index with Bjørnskov's (2008) measure which ranges from -1 to 1 and exhibits high values when right-wing parties dominate a parliament. It is obvious that except for the coefficient on the Bjørnskov's (2008) ideology index the expected signs of the new controls correspond to those of their predecessors. The coefficient sign of Bjørnskov's (2008) measure, on the contrary, is expected to be negative, since in comparison to Potrafke's (2009) measure the assignment of values to political orientations is carried out exactly the other way round. Transparency International's CPI as well as the EU dummy are incorporated unchanged in the estimations.

Column (2) of Table 2 reports the results from the OLS regression that includes all (modified) controls. Our main initial finding is again confirmed: as in Table 1, the coefficient of the corporate income tax rate is both positive and statistically highly significant and therefore indicative of a negative relationship between the level of corporate taxation and the degree of unbundling. Its size is furthermore almost identical to that of its counterpart in the most comprehensive basic regression (column (7) of Table 1).

The positive relationship between high government debt and low degrees of vertical separation already indicated by the basic results is also suggested when debt is measured as a proportion of the GDP. Contrary to its counterpart in the last column of Table 1, however, the robustness check coefficient reaches significance only at the $10 \%$ level. The size of the effect is rather minor, though: an increase in debts equal to ten percent of a country's GDP would raise the vertical integration index by less than 0.1 . The coefficient on energy supply per capita is only significant at the $10 \%$ level as well. It shows the expected negative sign and confirms the positive relationship between reform and a high energy intensity the comparable estimate in Table 1 already suggested. According to its size, each additional ton of oil equivalent supplied 
per person reduces the liberalization measure by approximately 0.4 . The separation-enhancing effects of a low degree of corruption is estimated to be lower than indicated before: compared to the basic regression, the impact induced by a one-unit increase in the corruption index is lowered to about two thirds; at the same time, the significance level is reduced to $5 \%$. Unlike the basic regression, the robustness check finally hints at higher levels of unbundling in EU member states. The coefficient of the EU dummy is statistically highly significant and suggests an EU membership to decrease the vertical integration index by one unit.

\subsubsection{Ordered Logit Regression with Alternative Controls}

The estimates of the ordered logit regression including the modified set of control variables are reported in the third column of Table 2. The results further substantiate the liberalizationhampering effect of heavily taxed corporate incomes, indicating the probability for full separation [integration] to decrease [increase] with higher corporate income tax rates: the coefficient on the tax rate is positive and reaches statistical significance at the $10 \%$ level. Moreover, the findings suggest a liberalization-enhancing effect of low levels of corruption and an EU membership with regard to the lowest and the highest degree of unbundling: the coefficients on both these controls are negative and statistically significant at the $10 \%$ and the $5 \%$ level, respectively.

Table 2B finally depicts the differences in conditional expected values calculated on the basis of the ordered logit model including the alternative controls. All $\Delta E(v i)$-values hint at lower levels of vertical separation in case of higher corporate income tax rates. As those in Table 2A, also the conditional expected values reported in Table $2 \mathrm{~B}$ suggest the effect of a higher tax rate on the unbundling intensity to be lower than their OLS counterpart in column (2) of Table 2: they range from about 0.02 to 0.015 and are hence one third to one half smaller than the OLS coefficient.

Table 2B: Changes in Expected VI Subindicator Values

\begin{tabular}{lllllll}
\hline \multicolumn{7}{c}{ corporate income tax rate base level $(\overline{\text { CITrate }})$} \\
& $10 \%$ & $20 \%$ & $30 \%$ & $40 \%$ & $50 \%$ & $60 \%$ \\
\hline$\Delta E(v i)$ & .0201 & .0195 & .0187 & .0179 & .0168 & .0154 \\
\hline \hline Note: Table 2B reports changes in the conditional expected values of the \\
vertical integration sub-indicator for the electricity sector induced by a one \\
percentage point increase in the corporate income tax rate, starting from the \\
respective base level CITrate. Conditional expected values are calculated \\
by means of the average predicted probabilities based on the ordered logit \\
estimates reported in column (3) of Table 2.
\end{tabular}




\subsubsection{Lagged Controls}

As a final robustness check, we re-estimate the regressions reported in the last column of Table 1 and all previous robustness checks with lagged proxies for energy intensity and corruption.

One might argue that the higher intensity of competition in electricity generation and supply that is expected to emerge in the course of increasing levels of unbundling affects the energy consumption of companies and households: because of the lower power prices prevailing in competitive markets, end-users might be less inclined to save energy. Since such a behavior would, in turn, raise the values of our energy intensity measures, an endogeneity problem would exist in all previous estimations. To ensure that we do not base our later considerations on the relationship between corporate income tax rates and vertical separation on biased results, we therefore lag the primary energy supply per GDP unit and per capita, respectively, by one period and check whether this will change the estimation results considerably.

We likewise lag the corruption index by one year to tackle another possible endogeneity problem: the public officials' susceptability to bribery might be higher, the higher the scope of regulatory interferences is (Tanzi, 1994; Mauro, 1996; Treisman, 2000). Due to the lack of competition usually prevailing in heavily regulated markets, the firms active in these markets enjoy considerable monopoly or oligopoly rents. This, in turn, might increase the bureaucrats' inclination to demand kickbacks, as they are aware of the regulated companies' willingness to pay them in order to shield their profitable environment against potential market entrants (Mauro, 1996; Ades and Di Tella, 1999).

Both theoretical and empirical findings provide some evidence for such a corruption-enhancing effect of excessive industry profits: in Ades and Di Tella's (1997a) model, the share of venal civil servants in the bureaucracy increases with increasing rents of the bribing regulatees. And regressions reveal a higher susceptability to bribery in countries where non-competitive profits exist due to either a market dominance of few firms (Ades and Di Tella, 1999) or one of the following government interventions: a restriction of foreign competition in general (Ades and Di Tella, 1997a, 1997b, 1999; Treisman, 2000) or with respect to public procurement, a discriminatory taxation, subsidization (Ades and Di Tella, 1997b) or regulatory interferences (Treisman, 2000); Ades and Di Tella's (1999) and Treisman's (2000) findings, though, lack statistical significance in some cases.

Again, estimation results suggest a statistically significant liberalization-hampering effect of high corporate income tax rates (see Tables 7 and 7A, respectively, in the Appendix for detailed results). When the original [alternative] set of controls (with both the energy intensity and the corruption proxies lagged by one year, though) is used, the highly significant OLS coefficient on the tax rate takes a value of 0.0346 [0.0334] which is virtually identical to the comparable estimate in column (7) of Table 1 [column (2) of Table 2]. As its counterpart in column (1) 
[(3)] of Table 2, the positive ordered logit coefficient on the corporate income is significant at the $5 \%$ [10\%] level; the changes in the conditional expected values of the vertical integration sub-indicator calculated on the basis of the ordered logit estimate range from 0.0166 to 0.0141 [from 0.0215 to 0.0163 ] (with values decreasing in the tax rate) and are hence effectively identical to the values reported in Table $2 \mathrm{~A}[2 \mathrm{~B}]$ as well.

\section{Estimation Results: VAT on Electricity}

\subsection{Basic Results}

We now examine whether the positive correlation between the taxation of power consumption and unbundling intensity indicated in Figure 2 can be corroborated by regression analysis. To identify the effect of electricity VAT rates on the level of vertical separation we start again with running linear OLS estimations with different combinations of control variables. We draw on all the controls already familiar from the regressions reported in Table 1.

Table 3 provides the estimation results. As with corporate income taxes, the regression output underpins the effect earlier implied by the scatterplot (Figure 2): higher electricity VAT rates are suggested to induce higher degrees of vertical separation. All tax rate coefficients are negative and - with one exception in the last column where only the $5 \%$ significance level is reached - statistically highly significant. Their values range from about -0.04 to slightly below -0.07 when the bivariate model in the first column is again neglected at this point. According to the estimate provided by the most comprehensive model in column (7), a ten percentage point increase in the tax rate reduces the integration index value by around $0.45^{7}$.

Signs and significance levels of the control variables largely correspond to those in Table 1: all coefficients on the lagged government debt are positive and statistically significant at the $1 \%$ level, again indicating a persistence of vertical integration especially in more highly indebted countries. However, although substantiating our findings from Section 3.1, the liberalizationhampering effect of budgetary deficits suggested by the results in Table 3 is rather surprising: based on the negative coefficient of the tax rate and the considerations outlined in the introduction and Section 2.2, we expect an increasing degree of vertical separation to enlarge the tax base of the electricity VAT. Regulators active in countries with high debts should hence promote unbundling measures to increase tax yields and thus (the chance for higher) government

\footnotetext{
${ }^{7}$ The different effects the rates of the electricity VAT and the corporate income tax are suggested to have on liberalization do not result from the different samples that are used for the estimations. When the regressions depicted in the last column of Table 1 and Table 3, respectively, are re-run applying the largest possible identical sample, findings again hint at a negative relationship between corporate income tax rate and unbundling and a positive one between electricity VAT rate and vertical separation. See columns (1) and (2), respectively, of Table 8 in the Appendix for detailed regression results.
} 
Table 3: OLS Regression Results

\begin{tabular}{|c|c|c|c|c|c|c|c|}
\hline & $(1)$ & $(2)$ & $(3)$ & $(4)$ & $(5)$ & (6) & $(7)$ \\
\hline elecVATrate & $\begin{array}{c}-.0962^{* * *} \\
(0.013)\end{array}$ & $\begin{array}{c}-.0653^{* * *} \\
(0.017)\end{array}$ & $\begin{array}{c}-.0632^{* * *} \\
(0.017)\end{array}$ & $\begin{array}{c}-.0713^{* * *} \\
(0.017)\end{array}$ & $\begin{array}{c}-.0639^{* * *} \\
(0.018)\end{array}$ & $\begin{array}{c}-.0466^{* * *} \\
(0.017)\end{array}$ & $\begin{array}{c}-.0439 * * \\
(0.018)\end{array}$ \\
\hline totaltaxrev $t-1$ & & $\begin{array}{l}1.8 \mathrm{e}-07 \\
(0.000)\end{array}$ & $\begin{array}{l}1.2 \mathrm{e}-07 \\
(0.000)\end{array}$ & $\begin{array}{c}-9.9 \mathrm{e}-08 \\
(0.000)\end{array}$ & $\begin{array}{l}3.5 \mathrm{e}-07 \\
(0.000)\end{array}$ & $\begin{array}{l}4.2 \mathrm{e}-07 \\
(0.000)\end{array}$ & $\begin{array}{c}4.4 \mathrm{e}-07 \\
(0.000)\end{array}$ \\
\hline totalgovdebt $_{t-1}$ & & $\begin{array}{c}3.9 \mathrm{e}-07^{* * *} \\
(0.000)\end{array}$ & $\begin{array}{c}3.7 \mathrm{e}-07^{* * *} \\
(0.000)\end{array}$ & $\begin{array}{c}4.2 \mathrm{e}-07^{* * *} \\
(0.000)\end{array}$ & $\begin{array}{c}3.8 \mathrm{e}-07^{* * *} \\
(0.000)\end{array}$ & $\begin{array}{c}5.2 \mathrm{e}-07^{* * *} \\
(0.000)\end{array}$ & $\begin{array}{c}5.2 \mathrm{e}-07^{* * *} \\
(0.000)\end{array}$ \\
\hline GDPgrowth $_{t-1}$ & & & $\begin{array}{l}-.0316 \\
(0.029)\end{array}$ & $\begin{array}{c}-.0596^{*} \\
(0.031)\end{array}$ & $\begin{array}{l}-.0356 \\
(0.031)\end{array}$ & $\begin{array}{l}-.0011 \\
(0.037)\end{array}$ & $\begin{array}{l}9.3 \mathrm{e}-04 \\
(0.037)\end{array}$ \\
\hline energysupGDP & & & & $\begin{array}{c}-9.755^{* * *} \\
(3.680)\end{array}$ & $\begin{array}{l}-4.613 \\
(4.248)\end{array}$ & $\begin{array}{c}-15.98^{* * *} \\
(5.047)\end{array}$ & $\begin{array}{c}-15.68^{* * *} \\
(5.110)\end{array}$ \\
\hline TIcor & & & & & $\begin{array}{c}-.4614^{* * *} \\
(0.118)\end{array}$ & $\begin{array}{c}-.3674^{* * *} \\
(0.122)\end{array}$ & $\begin{array}{c}-.3624^{* * *} \\
(0.123)\end{array}$ \\
\hline ideopotr & & & & & & $\begin{array}{c}.2851^{* * *} \\
(0.079)\end{array}$ & $\begin{array}{c}.2843^{* * *} \\
(0.079)\end{array}$ \\
\hline EUdum & & & & & & & $\begin{array}{l}-.1622 \\
(0.370)\end{array}$ \\
\hline constant & $\begin{array}{c}5.251^{* * *} \\
(0.184)\end{array}$ & $\begin{array}{c}4.197^{* * *} \\
(0.284)\end{array}$ & $\begin{array}{c}4.240^{* * *} \\
(0.300)\end{array}$ & $\begin{array}{c}6.677^{* * *} \\
(1.045)\end{array}$ & $\begin{array}{c}9.097^{* * *} \\
(1.099)\end{array}$ & $\begin{array}{c}10.72^{* * *} \\
(1.369)\end{array}$ & $\begin{array}{c}10.55^{* * *} \\
(1.437)\end{array}$ \\
\hline country dummies & no & yes & yes & yes & yes & yes & yes \\
\hline year dummies & no & yes & yes & yes & yes & yes & yes \\
\hline$R^{2}$ & .0991 & .8343 & .8348 & .8381 & .8406 & .8561 & .8562 \\
\hline$N$ & 491 & 381 & 381 & 381 & 361 & 327 & 327 \\
\hline
\end{tabular}

appropriations rather than defer them. Moreover, also our alternative explanation suggesting regulators to perceive a high government debt as an indicator of an economic downturn is at odds with the positive estimates on debt: as outlined in Section 3.2.1, we expect ministry and agency employees to promote competition by increasing the unbundling intensity when indebtedness is high, but again coefficients hint at the opposite. However, as in Table 1, the estimates suggest the size of the effect to be virtually zero, again indicating that by the amount of the national debt in the previous year does not affect the level of vertical separation in a notable way.

As in Table 1, the estimate on the lagged GDP growth rate reaches statistical significance (at the 10\% level) only when some controls are not included in the regression yet. The only significant coefficient in column (4) again rather challenges the "crisis hypothesis" and indicates that an unusually high growth rate would be necessary to change the unbundling measure in a notable way: an increase in the growth rate by ten percentage points lowers the index value by about 0.6 .

The coefficient of the lagged energy intensity is consistently negative and reaches significance at the $1 \%$ level in all but the fifth column (where it becomes statistically insignificant). The most comprehensive model specification hints at an impact of an economy's energy use that is 
even higher than that indicated in the last column of Table 1: an increase of 0.1 tonnes of oil equivalent in the amount of primary energy needed to produce 1000 dollars of GDP reduces the integration index in the following year by almost 1.6.

Unlike in Table 1, the corruption index is consistently statistically significant at the $1 \%$ level; the sizes of the coefficients, however, do not deviate substantially from the values their significant counterparts take in Section 3.1. According to the estimate in the last column of Table 3, a one-unit increase in the corruption index decreases the liberalization measure by slightly more than 0.35 units.

Compared to the results reported Section 3.1, the highly significant estimates of the ideology effect rise. They imply that a change from a right-wing to a left-wing government would lead to an integration index increase of above 1.1; this exceeds the impact suggested by the estimation outcome depicted in Table 1 by more than 0.3 .

Finally, the coefficients on the lagged tax revenue and EU membership are again statistically insignificant.

\subsection{Robustness Checks}

We check the robustness of the results by repeating the procedure from Section 3.2: First, we re-run the most comprehensive basic OLS regression using ordered logit as estimation method. Then, we modify the controls for tax yields, debt, economic performance, energy intensity and government ideology and estimate an OLS model. Next, we run an ordered logit regression including the modified set of control variables. Finally, we re-estimate the basic OLS regression that comprises all controls as well as the three robustness checks described previously with the proxies for both energy intensity and corruption being lagged by one year.

Column (1) of Table 4 depicts the results of the ordered logit estimation containing the initial control variables. As in Table 3, a liberalization-enhancing effect of high electricity VAT rates is suggested: the coefficient on the tax rate is negative and statistically highly significant, indicating the likelihood for full unbundling [integration] to increase [decrease] with increasing tax rates. Substantiating the findings from the basic regression, the highly significant coefficients on the energy intensity proxy and the ideology index hint at higher reform efforts in countries with a high energy use and with right-wing governments. Likewise, also the estimate on the corruption measure (being significant at the $5 \%$ level) confirms the finding from Table 3 and indicates higher level of unbundling in less corrupt countries. Finally, the positive and statistically highly significant coefficient on tax yields suggests the probability for a fully integrated [separated] power sector to be lower in case of high public revenues, which is in line with our considerations: as the negative estimate on the tax rate makes us expect that unbundling increases the base of the electricity VAT, regulators striving for high appropriations should be prone to fully separate the networks; with tax yields being already high, we expect the incentive to do so to be lower. 
Table 4: Robustness Checks

\begin{tabular}{|c|c|c|c|}
\hline & (1) & $(2)$ & $(3)$ \\
\hline elecVATrate & $\begin{array}{c}-.1879^{* * *} \\
(0.057)\end{array}$ & $\begin{array}{c}-.0450^{* *} \\
(0.018)\end{array}$ & $\begin{array}{c}-.1860^{* * *} \\
(0.063)\end{array}$ \\
\hline totaltaxrev $_{t-1}$ & $\begin{array}{c}7.0 \mathrm{e}-06^{* * *} \\
(0.000)\end{array}$ & & \\
\hline $\operatorname{taxrevGDP}_{t-1}$ & & $\begin{array}{c}.0549 \\
(0.040)\end{array}$ & $\begin{array}{c}.115 \\
(0.138)\end{array}$ \\
\hline totalgovdebt $_{t-1}$ & $\begin{array}{c}-6.0 \mathrm{e}-07 \\
(0.000)\end{array}$ & & \\
\hline govdebtGDP $_{t-1}$ & & $\begin{array}{c}.0075 \\
(0.005)\end{array}$ & $\begin{array}{l}-.0188 \\
(0.023)\end{array}$ \\
\hline GDPgrowth $_{t-1}$ & $\begin{array}{l}-.0755 \\
(0.114)\end{array}$ & & \\
\hline GDPcapgrowth $_{t-1}$ & & $\begin{array}{c}.0118 \\
(0.031)\end{array}$ & $\begin{array}{c}.0531 \\
(0.113)\end{array}$ \\
\hline energysupGDP & $\begin{array}{c}-72.83^{* * *} \\
(16.64)\end{array}$ & & \\
\hline energysupcap & & $\begin{array}{c}.0961 \\
(0.322)\end{array}$ & $\begin{array}{l}-.3991 \\
(1.005)\end{array}$ \\
\hline TIcor & $\begin{array}{c}-1.216^{* *} \\
(0.505)\end{array}$ & $\begin{array}{c}-.4995^{* * *} \\
(0.121)\end{array}$ & $\begin{array}{c}-1.641^{* * *} \\
(0.477)\end{array}$ \\
\hline ideopotr & $\begin{array}{c}.5997^{* * *} \\
(0.226)\end{array}$ & & \\
\hline ideobjor & & $\begin{array}{c}-.7264^{* * *} \\
(0.251)\end{array}$ & $\begin{array}{c}-1.962^{* *} \\
(0.939)\end{array}$ \\
\hline EUdum & $\begin{array}{l}-1.556 \\
(1.272)\end{array}$ & $\begin{array}{l}-.7836^{*} \\
(0.405)\end{array}$ & $\begin{array}{l}-1.041 \\
(1.077)\end{array}$ \\
\hline constant & & $\begin{array}{c}6.019^{* * *} \\
(1.935)\end{array}$ & \\
\hline country dummies & yes & yes & yes \\
\hline year dummies & yes & yes & yes \\
\hline$R^{2}$ & & .8481 & \\
\hline Pseudo $-R^{2}$ & .6731 & & .6678 \\
\hline$N$ & 327 & 287 & 287 \\
\hline
\end{tabular}

Note: Columns (1) and (3) show estimation results of ordered logit regressions, column (2) those of a standard linear OLS estimation. Dependent variable is the vertical integration sub-indicator for the electricity sector as described in Conway and Nicoletti (2006). Robust standard errors in parentheses. $* * * / * * / *$ denotes statistical significance at the $1 \% / 5 \% / 10 \%$ level.

Finally, we compute differences in conditional expected values as outlined in Section 3.2 to quantify the unbundling index reduction induced by a one percentage point increase in the VAT rate. Results for exemplary tax rate base levels relevant for our sample are depicted in 
Table 4A: Changes in Expected VI Subindicator Values

\begin{tabular}{|c|c|c|c|}
\hline & \multicolumn{3}{|c|}{ electricity VAT rate base level $(\overline{\text { elecVATrate }})$} \\
\hline & $5 \%$ & $15 \%$ & $20 \%$ \\
\hline$\Delta E(v i)$ & -.0394 & -.0500 & -.0551 \\
\hline \multicolumn{4}{|c|}{$\begin{array}{l}\text { Note: Table } 4 \mathrm{~A} \text { reports changes in the conditional expected values of the } \\
\text { vertical integration sub-indicator for the electricity sector induced by a one } \\
\text { percentage point increase in the electricity VAT rate, starting from the re- } \\
\text { spective base level elecVATrate. Conditional expected values are calculated } \\
\text { by means of the average predicted probabilities based on the ordered logit } \\
\text { estimates reported in column (1) of Table } 4 \text {. }\end{array}$} \\
\hline
\end{tabular}

Table 4A. They range from approximately -0.039 to -0.055 and confirm the positive relationship between the taxation of electricity consumption and vertical separation suggested by all previous findings. Besides, it becomes apparent that, unlike in the case of the corporate income tax rate, the marginal effects calculated on the basis of the ordered logit outcome partly undercut (for lower base levels) and partly exceed (for higher base levels) their OLS counterpart from the last column of Table 3 . This also results in considerably lower deviations of reported $\Delta E(v i)$-values from the OLS estimate: they reach only about 25 percent of the size of the OLS coefficient at the maximum.

The results of the OLS regression including the modified set of controls are reported in column (2) of Table 4 and substantiate the main finding of all previous estimations: again, the VAT rate coefficient implies a positive relationship between tax rate and degree of unbundling. Beyond that, the significance level, the sign and virtually also the size of the taxation estimate in column (1) and its counterpart in the most comprehensive regression model outlined in Table 3 (column (7)) coincide.

The negative and statistically highly significant corruption coefficient in column (2) corroborates the findings from the basic regression. Its size, however, implies a stronger separationenhancing effect of low levels of bribery than the estimate in the last column of Table 3: a one-unit increase in Transparency International's (2012) measure is suggested to lower the vertical integration index by nearly 0.5. The impact of a government's ideology on the degree of liberalization might also be stronger than indicated by the basic OLS regression: being significant at the $1 \%$ level, the coefficient of the alternative ideology measure hints at a reduction of the integration index by nearly 1.5 whenever a left-wing government is replaced by a rightwing successor. Besides, column (2) reveals a separation-enhancing effect of an EU membership, which is not identified in Table 3. According to the estimate in Table 4 (which is, however, only significant at the $10 \%$ level), being a member states decreases the liberalization index value by more than 0.75 .

The third column of Table 4 then shows the outcome of the ordered logit estimation containing the alternative controls. The negative and statistically highly significant tax rate coefficient corroborates the positive relationship between high electricity VAT rates and vertical separation 
Table 4B: Changes in Expected Vi Subindicator Values

\begin{tabular}{|c|c|c|c|}
\hline & \multicolumn{3}{|c|}{ electricity VAT rate base level $(\overline{\text { elecVATrate }})$} \\
\hline & $5 \%$ & $15 \%$ & $20 \%$ \\
\hline$\Delta E(v i)$ & -.0378 & -.0475 & -.0523 \\
\hline \multicolumn{4}{|c|}{$\begin{array}{l}\text { Note: Table 4B reports changes in the conditional expected values of the } \\
\text { vertical integration sub-indicator for the electricity sector induced by a one } \\
\text { percentage point increase in the electricity VAT rate, starting from the re- } \\
\text { spective base level elecVATrate. Conditional expected values are calculated } \\
\text { by means of the average predicted probabilities based on the ordered logit } \\
\text { estimates reported in column (3) of Table } 4 \text {. }\end{array}$} \\
\hline
\end{tabular}

indicated by the regression results in both Table 3 and columns (1) and (2) of Table 4. Likewise, the liberalization-enhancing effect of low corruption levels and right-wing governments are further substantiated: the corresponding ordered logit estimates are negative and significant at the $1 \%$ and $5 \%$ level, respectively.

Differences in the conditional expected values of the vertical integration sub-indicator calculated on the basis of the ordered logit regression including the modified set of controls are reported in Table 4B. Further confirming all previous findings, the depicted $\Delta E(v i)$-values suggest the degree of unbundling to rise when the electricity VAT rate is increased by one percentage point; the effect is indicated to be higher, the higher the tax rate before the increase is. The values lie between about -0.038 and -0.05 , hinting at a lower influence of taxation on vertical separation than their OLS counterpart when the VAT rate is low and a higher one when power consumption is rather heavily taxed (as it is also suggested by the results depicted in Table 4A); deviations from the OLS estimate reported in column (2) of Table 3 amount to not more than 20 percent of the OLS coefficient.

Finally, also the regressions including the lagged proxies for energy intensity and corruption suggest a liberalization-enhancing effect of high electricity VAT rates (see Tables 9 and 9A, respectively, in the Appendix for detailed results). The OLS estimation including the (otherwise) original [alternative] set of controls provides a coefficient on the tax rate of -0.0443 [-0.0480] that reaches statistical significance at the $5 \%$ level and is virtually identical to its counterpart in column (7) of Table 3 [column (2) of Table 4]. As the comparable estimate in column (1) [(3)] of Table 4, the ordered logit coefficient on the electricity VAT rate is negative and highly significant; the $\Delta E(v i)$-values of the vertical integration sub-indicator calculated on the basis of the ordered logit estimate range from -0.0403 to -0.0541 [from -0.0411 to -0.0566] (with values decreasing in the tax rate) and are thus almost identical to the values depicted in Table 4A [4B].

\section{The Role of Regulators}

In sum, our findings thus hint at a liberalization-enhancing effect of low corporate income tax rates and high VAT rates on electricity. As already outlined in the introduction, we conjecture 
that the decision-makers responsible for both organization and regulation of national electricity industries play an important role for these results. In the following, we will explain this notion step by step: initially, we will elaborate on why we assume those in charge of electricity market surveillance to strive for high state appropriations for the institution they work for; we will distinguish at this point between regulatory arrangements before (see Section 5.1) and after 1990 (Section 5.2), the year when the reform process in the power sector gathered momentum (Newbery, 2009). Subsequently, we will discuss why we furthermore expect an interest in high state budgets to exist among those responsible for regulation (Section 5.3). We will then draw on all these considerations to finally explain why we suspect that low corporate income tax rates (Section 5.4.1) and high electricity VAT rates (Section 5.4.2) induce both officials from ministries monitoring the electricity market and members of regulatory agencies to raise the level of unbundling.

\subsection{The Pre-1990 Period: Regulation by Ministries}

Before independent regulatory authorities were established in the course of energy sector liberalization and gradually fulfilled more and more tasks in the regulation of electricity markets, primarily ministries influenced all relevant decisions in the regulatory process (OECD/IEA, 2001). The monitoring of the power sector was hence conducted by ministry officials that most likely did not only pursue their formal objective, the supervision of the vertically integrated utilities active in all stages of the sector's value chain (generation, transmission, distribution and retail) at that time (Viscusi et al., 2005, ch. 12; Newbery, 2009). Instead, the theory of bureaucracy - originally going back to Niskanen (1968), revised by Migué and Bélanger (1974) and Niskanen (1975), and topic of various other publications (see, e.g., Downs, 1967, ch. IX; Rourke, 1984, ch. 4; Tullock et al., 2002, ch. 5) - suggests that they might likewise have aimed at maximizing their ministry's power and, above all, its budget. Theory explains the officials' interest in a high funding for their employer as follows (Niskanen, 1968, 1975; Migué and Bélanger, 1974): with increasing financial means, a state institution gains power and reputation within the political process and its workforce gets higher salaries and additional perquisites; effects that, in turn, increase the civil servants' utility. The improvement in the officials' (non-

)monetary remuneration is assumed to primarily result from an (illegitimate) siphoning off of resources that is possible for three reasons: the respective office is the only supplier of the output, i.e., the state does not have a (competing) alternative to satisfy its demand for the good or service the institution provides; the supply cannot be rewarded on a per unit basis, so that a fixed amount of funds has to be appropriated; and superordinated politicians lack the information essential to assess whether the requested funding is necessary to realize the output provided and therefore the possibility to prevent fraudulent use.

In power market regulation all these issues are prevalent: the industry is usually monitored 
by one single institution; surveillance activities are an intangible "output" (Dunleavy, 1985) the regulatory body's budget cannot be linked with; and specialist knowledge is inevitable to be able to meet the challenges of electricity regulation. It thus seem reasonable to assume that the regulatory actors before 1990 were, as suggested by the theory of bureaucracy, at least partly interested in high appropriations for their ministries.

This view is further supported by empirical research that provides some evidence for the interest of bureaucrats in high budget appropriations and the associated merits: various papers identify strong preferences for - often considerable - budget increases for the own institution to exist among heads of American state (Bowling et al. 2004; Ryu et al., 2007; ASAP, 2008) and Norwegian municipal (Jacobsen, 2006) agencies, higher-level officials in Finish ministries (Venetoklis and Kiander, 2006) and bureaucrats in Turkish local authorities (Bağdigen, 2003); the Norwegian senior bureaucrats were furthermore found to favor an allocation of ample funds to internal administration, which is interpreted as a potential expression of their striving for a high bureaucratic slack (Jacobsen, 2006). Studies surverying the actual budget requests of American agencies (which are, according to Ryu et al. (2007), significantly affected by the aforementioned preferences) draw a similar picture: they reveal the demands for financial means to substantially increase in most cases (Sharkansky, 1965, 1968; LeLoup and Moreland, 1978; Lauth, 1986; Thompson, 1987; Ryu et al., 2007; ASAP, 2008). And also Blais and Dion (1990), discussing the results of several publications empirically analyzing the bureaucracy model, conclude that the reviewed findings support the theory. They base their view inter alia on Sigelman (1986), whose paper once more suggests preferences for high appropriations to prevail in governing bodies of U.S. agencies; on Krueger (1988) who finds the number of applicants for federal jobs to increase in America when the public-private sector wage ratio increases; and on Grandjean (1981), whose results (albeit not entirely without contradictions) hint at higher wages for fulltime, white-collar officials in U.S. agencies with a steadily growing number of employees.

\subsection{The After-1990 Period: Regulation by Independent Agencies}

With the beginning of national reform processes in the electricity sector around 1990, (purportedly) independent regulatory authorities (IRAs) were established (Gilardi, 2008, ch. 6) to control the industry's natural monopolies persisting in transmission and distribution. Apart from their autonomy from regulatees, the authorities' independence from the state (including a financial autonomy) is rated as being essential for the IRAs' functioning: the distance from politics is supposed to prevent government interference in regulatory decisions (Smith, 1997). Nevertheless, we expect an interest in high government appropriations to exist also among regulators. We will substantiate this assumption by initially explaining why it is reasonable to assume that IRA members do not differ from ministry officials in their striving for high budgets for the institution they work for; then, we will discuss why this is equivalent to an interest in a 
high funding provided by the state.

Two possible explanation exist for why agency employees might aim for high financial resources for their employer. First, it might be possible that regulators pursue personal objectives that deviate from the authority's official task (Kay and Vickers, 1990) and are basically the same as the goals Niskanen $(1968,1975)$ ascribes to bureaucrats (Noll, 1989; Train, 1991, ch. I.1). The extreme complexity prevailing in regulatory environments after liberalization necessitates experts to be employed in authorities (Thatcher, 2002a). Such specialist working in state agencies, in turn, are expected to be eager for realizing (also) personal ends and to be willing to both neglect their official mandate and to accept societal detriments just to promote their career or to benefit their institution. Their self-serving behavior is conjectured to remain undetected as neither politicians nor citizens possess the knowledge necessary to evaluate the experts' activities and since their output is furthermore often intangible (Moe, 1989); both the discretionary leeway and the (substantial) authority granted to the specialists in the course of their work are then assumed to enable them to enforce the decisions that serve their personal interests (Moe, 1990). Given this tarnished image of publicly employed experts, expecting also electricity market regulators to strive for high financial means for their agencies appears reasonable.

The second (and entirely different) possible reason for why a striving for high financial resources might exist within IRAs are agency members aiming for an effective regulation: on the one hand, the growing scientification of utility regulation requires both the aforementioned recruitement of profound expert knowledge (Thatcher, 2002a) and the incurrence of significant information costs (Agrell and Gautier, 2010) on the part of the agency; on the other hand, the companies which energy authorities have to supervise are equipped with considerable resources (Thatcher, 2002b) that can be abused to impede the regulators' work. To overcome all these problems and properly fulfil their tasks, IRAs thus need appropriate financial means (OECD/IEA, 2001; Thatcher and Stone Sweet, 2002); in particular, since the agencies' challenges to hire specialists and to counter the regulatees' financial superiority are obviously closely connected: with expertise being demanded not only by authorities but also by regulated firms (OECD/IEA, 2001), the possibility to pay higher salaries due to a higher budget increases the agencies' chances to get competent staff (Smith, 1997) by outdoing the industry. Consequently, we expect an interest in a good budgetary position of their authority also to exist among regulators when they exclusively pursue their public mission.

We finally want to explain why striving for high financial resources (and salaries) basically amounts to striving for high government appropriations for the agency. A first hint is given by OECD/IEA (2001), revealing that an important source of the budgets of independent authorities regulating OECD electricity markets is the public income from general taxation. Several studies analyzing the financial dependency of regulators from government provide further evidence.

Hanretty and Koop (2009) survey 175 regulators from 88 countries (including 31 energy 
regulators) and find that according to their statutes the funding of more than 60 percent of the authorities comes either fully or partially from government.

On a scale from 0 to 1 (where 1 stands for full statutory independence from government) 14 European electricity regulators reach an average financial and organisational independence of slightly more than 0.75 (Gilardi, 2008, ch. 8). This suggests that a certain budgetary dependence of the authorities on governments exists.

The survey results of Johannsen et al. (2005) are in line with these findings as well. The study shows that eight out of 15 energy regulators get all or parts of their funding from government. In addition, the government in four out of the 15 countries is in charge of the authorities' personnel policy and, inter alia, determines the level of salaries in the course of this function.

Finally, also the CEER (2005) confirms a limited financial independence of European energy IRAs: in eleven out of 27 countries surveyed the regulators are not financially autonomous since their budget forms part of the state budget. In eight of the countries the regulatees are not involved in the funding of the authority, implying that the state alone has to provide the financial means required to ensure the regulator's operations.

\subsection{The Interest in a Large State Budget}

We now explain why we expect officials employed in ministries and independent authorities responsible for electricity market regulation to be interested also in a high state budget when they favor high appropriations for their agency. The overall national budget is often described as a "pie" of which public agencies aim to get a slice as large as possible (Peters, 1978, ch. 7; Bowling et al., 2004). Since an increase in the size of the "pie" allows slices (i.e., the appropriations) for the single authorities to become larger as well (Blais and Dion, 1990; Wildavsky and Caiden, 2004, ch. 3), ministry members and regulators striving for additional resources for their institution should prefer a generous state budget, too (Downs, 1967, ch. IX; Hood et al., 1984; Bowling et al., 2004).

Empirical findings are in line with these considerations. First, results hint at a struggle for the "pie" to indeed exist between agencies: Jacobsen (2006) shows that the same authority heads that prefer additional means to be appropriated for their own agency virtually always oppose budget increases (and, in few cases, even favor budget cuts) for Norwegian municipal agencies active in different remits. Venetoklis and Kiander (2006) reveal that the Finnish senior officials that generally strive for higher resources for departments and tasks attached to their ministry want the appropriations for other ministries to decrease in numerous cases. And the interviews conducted by Bağdigen (2003) convey the impression that Turkish bureaucrats try to outmaneuver their colleagues to secure additional funds for the local authority they are employed by.

Second, given the results of Hood et al. (1984), the assumption that public officials benefit 
from a larger overall "pie" seems plausible as well: their findings provide some evidence for payments and pay-related perks for officials in U.K. ministerial departments to increase on both the aggregate and the per-capita level in cases of expansions of the central government's budget.

And finally, also the expectation that public employees favoring high appropriations for their own institution want the state budget to be high, too, is supported by the data: a survey in the American State Administrators Project (ASAP, 2008) finds that almost three quarters of the officials included in the study endorse an increase in total state expenditures, while Bowling et al. (2004) show that, depending on the year of the period they analyze (1964-1998), about half to three quarters of the U.S. civil servants surveyed would prefer both their agency and the state budget to be higher.

\subsection{The Effect of Tax Rates on Regulatory Decisions}

\subsubsection{Corporate Income Tax}

We now illustrate why we expect ministry officials and regulators who are interested in both high government appropriations for their institutions and a high state budget to particularly foster unbundling when corporate income tax rates are low. The basic idea is as follows: the explanations in Section 5.3 suggest that the funding for the ministry or agency in charge of regulation is higher (or, at least, is expected to be so by the institution's employees), the larger the state budget is. Furthermore, it seems reasonable to assume that the state budget, in turn, is higher, the higher the tax yields are; with high public revenues, also state expenditures are probably higher. Regulators aiming for substantial financial means for the institution they work for should hence take their decisions in a way that raises overall tax revenues or, if this is impossible, that reduces tax yields as little as possible. This most likely increases [prevents cuts in] the state budget, accordingly raising the probability that the ministry or the agency, respectively, receives higher [stable] government appropriations. As regulatory actors are unable to affect the tax rate, increasing [maintaining] tax revenues implies broadening [lowering] the tax base [as little as possible].

Let us compare the extreme cases of vertical connections in the electricity sector to discuss these considerations with respect to the corporate income tax rate: in case of full integration, the linkages between the natural monopoly (i.e., the grids) and generation, wholesale, and retail prevent any competition in the latter areas of the industry. This generates monopolistic market structures also in the potentially competitive stages of the value chain. With full separation, on the contrary, commercial interests of the natural monopoly in generation, wholesale and retail companies no longer exist. Hence, full competition arrives in this areas (OECD, 2001). Furthermore, microeconomic theory shows that, compared to a competitive market, industry profits are higher when demand is satisfied by a monopolist; the positive effect on profits that result from 
the higher price a monopolistic firm charges dominates the negative effect the associated output reduction entails (Katz and Rosen, 1998, ch. 13.2).

Fostering competition in generation, wholesale, and retail by implementing stricter forms of unbundling hence reduces the base of the corporate income tax: designed as a profit tax with payments to capital being treated as non-deductible expenses, the corporate income tax can be seen as a tax on capital costs (Myles, 1995, ch. 8.2.2). The remuneration of (equity) capital, in turn, is usually higher when profits are high, so that ministry officials or regulators requiring vertically integrated electricity utilities to separate their grids would eventually act against their own interests. Consequently, we expect an incentive to refrain from realizing unbundling measures to exist among regulatory actors and we furthermore expect it to be higher, the higher the corporate income tax rate is ${ }^{8}$ : as soon as competition-enhancing steps of reform reduce the tax base by a certain amount, the loss in tax revenues and thus also the associated cuts in the ministry's or the authority's budget increase in the tax rate. Officials and regulators that are more reluctant to foster vertical separation the more they benefit from high payments to capital made in non-competitive environments might hence be a possible explanation for the negative relationship between corporate income tax rates and unbundling intensity suggested by the estimation results.

With this conceivable explanation for the regression outcome put forth, we now briefly want to discuss the problem of reverse causality. Since we apply OLS and ordered logit regressions to estimate the effect of tax rates on the degree of unbundling, we cannot rule out that our estimates are biased since the direction of effect runs opposite and taxation is affected by the level of vertical separation. However, existing literature discussing the determinants of the design of tax systems (see, e.g., Owens, 2006; James and Edwards, 2008; Brys et al., 2011; Bird and Wilkie, 2012) does not identify the regulations implemented in a country's electricity sector to be a relevant factor at all, so we expect endogeneity caused by reverse causality not to be an issue in our estimations.

\subsubsection{VAT on Electricity}

Given the previous considerations on the relationship between corporate income tax rate and the degree of vertical separation, the estimation results from Section 4 should finally make us expect a positive effect of higher unbundling levels on electricity VAT revenues: we assume regulators to refrain from implementing steps of reform when liberalization decreases the base of a tax and high tax rates imply that the loss in state revenue resulting from such a tax base reduction is considerable; if, conversely, high tax rates foster the implementation of reform measures (as the regression outcome suggests in the case of the electricity VAT), this should

\footnotetext{
${ }^{8}$ With the electricity industry being a very capital-intensive sector, we reasonably assume the corporate income tax not to distort factor input decisions and thus profit-maximizing outputs.
} 
accordingly be induced by a raise in the tax base. In this case, the additional tax yields after reform would be higher, the higher the tax rate, and an authority interested in fiscal revenue would increasingly promote unbundling the more heavily electricity consumption is taxed.

Whether increasing the level of vertical separation indeed raises the base of the electricity VAT and thus the tax yields, though, is not clear: with a higher competition in the power market, (pre-tax) prices drop and the electricity amount the consumers purchase increases, so that the tax base is affected by two opposing effects (in addition, also levying a VAT itself creates both price and quantity effects (Stiglitz, 2000, ch. 18)). In the following, we will therefore draw on empirical research on the price elasticity of electricity demand to analyze whether the positive relationship between VAT rates and unbundling suggested by our findings might, as conjectured, be induced by the regulators' higher incentives to benefit from a broad tax base that prevail when power consumption is taxed more heavily. Let $P(Q)$ denote the (decreasing) inverse aggregate after-tax demand for power and $t>0$ the VAT rate, so that

$$
\operatorname{VAT}(Q)=t \cdot P(Q) \cdot Q
$$

describes total electricity VAT revenues. To let an increase in the market equilibrium quantity together with the associated reduction in the equilibrium price (or, put differently, an introduction of more competition) be profitable from the regulator's point of view,

$$
\frac{\partial V A T(Q)}{\partial Q}=t \cdot\left[P(Q)+P^{\prime}(Q) \cdot Q\right]>0
$$

has to hold; the additional tax receipts generated by the marginal power unit have to outweigh the loss in tax revenues that results from the price decrease for inframarginal units. Rearranging (1) yields

$$
-\frac{P(Q)}{Q} \cdot \frac{1}{P^{\prime}(Q)}>1,
$$

where the left-hand side is the price elasticity of electricity demand (Varian, 2010, ch. 15.5), multiplied by minus one. Fostering competition by implementing stricter rules on unbundling can hence only be optimal for a regulatory actor interested in high revenues from taxing power consumption when electricity demand is price elastic; in this case, the tax base increases when the equilibrium quantity is raised and also the conjectured incentive to promote reform more strongly when the tax rate is high might indeed exist. 
Empirical findings suggest the power demand to be price elastic in some of the countries of our sample to estimate the effect of electricity VAT rates on unbundling (we discuss the results for long-run elasticities at this point, as reducing the degree of vertical integration in the power sector is a lengthy process): elasticity values smaller than minus one are estimated for the Finnish (Madlener et al., 2011), the German (Narayan et al., 2007) and the Japanense (Narayan et al., 2007; Madlener et al., 2011) residental electricity demand. For several sample countries, though, empirical results indicate the exact opposite: for Austria, Denmark, Germany, Ireland, the Netherlands, Norway, South Korea (Madlener et al., 2011), Canada (Narayan et al., 2007), France, the UK (Narayan et al., 2007; Madlener, 2011), Spain (Madlener et al., 2011; Blázquez et al., 2012) and Italy (Narayan et al., 2007; Madlener et al., 2011; Dicembrino and Trovato, 2013) household electricity demand is estimated to be inelastic; furthermore, results suggest a price inelastic industrial power demand to exist in Italy (Dicembrino and Trovato, 2013) and Germany (Madlener et al., 2011; in the food and tobacco, the chemicals, the pulp and paper, the non-metallic minerals and the transport equipment subsectors of manufacturing).

The possible explanation for the positive relationship between electricity VAT rates and unbundling intensity we provide is hence at odds with most of the empirical findings on the long-run price elasticity of power demand: with an inelastic demand, the lower price power producers can charge in more competitive markets has a stronger effect on the tax base than the associated increase in electricity demand, so that, overall, the base of the electricity VAT decreases with stricter forms of unbundling. Tax revenue reductions are then higher, the higher the tax rate is, so that, following our original notion, higher VAT rates should increase the incentive for regulatory actors interested in high appropriations for their institution to refrain from implementing (further) steps of reform (just as in the case of the corporate income tax).

One might argue that the discrepancy between our regression results and our assumption that avaricious officials and regulators determine the liberalization speed results from inconsistent estimates. The degree of unbundling might affect the rate of the electricity VAT, implying that the coefficient on the VAT rate would be biased due to reverse causality. As already outlined in the previous section, however, a country's regulatory regime in the power sector is not found to be a factor having an influence on the design of the tax system by the relevant literature (see, e.g., Owens, 2006; James and Edwards, 2008; Brys et al., 2011; Bird and Wilkie, 2012); we therefore expect the estimates challenging our assumption not to be induced by reverse causality.

Another possible explanation for the unexpected positive relationship between electricity VAT rates and unbundling intensity might be that the estimates on the VAT rate are inconsistent as they suffer from an omitted variable bias (Wooldridge, 2002, chs. 4.1 and 4.3.1). The estimation results reported in Table 5 might indeed create this impression (see column (3) in Table 8 in the Appendix for full results): while an estimation based on the same sample and with the same controls, but not including the corporate income tax rate as additional 


\begin{tabular}{lc}
\multicolumn{2}{l}{ TABLE 5: OLS REGRESSION RESUlts } \\
\hline & $(1)$ \\
\hline CITrate & $.0520^{* * *}$ \\
& $(0.011)$ \\
elecVATrate & -.0076 \\
& $(0.018)$ \\
\hline all controls & yes \\
country dummies & yes \\
year dummies & yes \\
\hline$R^{2}$ & .8658 \\
$N$ & 326 \\
\hline \hline & Note: Estimation results of standard lin- \\
ear OLS estimation; full estimation re- \\
sults can be found in column (3) of Ta- \\
ble 8 in the Appendix. Robust standard \\
errors in parentheses. $* * *$ denotes statis- \\
tical significance at the 1\% level.
\end{tabular}

regressor provides a VAT rate estimate of -0.0437 significant at the $5 \%$ level (see column (2) of Table 8), the findings in Table 5 raise doubts whether an effect of the electricity VAT rate on vertical separation exists at all; the coefficient on the VAT rate is statistically insignificant and of negligible size (-0.0076) when the rates of both the VAT and the corporate income tax are included in the regression. The estimate on the corporate income tax rate, on the contrary, remains virtually unaffected by an inclusion of the electricity VAT rate as additonal regressor and drops only slightly from 0.0539 (see column (1) in Table 8) to 0.0520 , with both estimates being statistically highly significant.

The results from the regression comprising both tax rates as explanatory variables hence indicate that officials and regulators striving for high ministry and agency budgets, respectively, might base their regulatory decisions only on how further unbundling measures affect the base of the corporate income tax; changes in the base of the electricity VAT, by contrast, are suggested not to have any influence.

\section{Conclusion}

Our paper provides a possible reason for diverging degrees of electricity market liberalization that goes beyond the scope of common explanations: based on the (substantiated) assumption of regulatory decision makers striving for the highest possible appropriations, we show that the linkage between the public budget and the regulator's funding existing in both past and present might influence a country's reform efforts in the power industry. Estimation results suggest that higher corporate income tax rates are significantly related to lower levels of vertical separation implemented in the sector. Since the increase in competition associated with higher 
unbundling intensities reduces the base of the corporate income tax, the loss in tax revenues is higher, the higher the tax rate is. Lower tax yields, in turn, lead to lower funding of ministries and regulatory authorities, so we conjecture ministry officials and regulators to refrain from implementing steps of reform especially when corporate income is heavily taxed: the size of the budget cut that is to be expected increases in the tax rate.

This means that, in electricity markets, a clear delineation of the regulator's budgetary or financial interests from its regulatory goals is vital to ensure the achievement of these aims. As long as the authority's budget and/or the salaries paid to its employees are indirectly affected by the sectoral tax payments that, in turn, depend on the prevailing market structure, competitionhampering regulations such as an insufficient degree of unbundling cannot be ruled out.

Empirical findings furthermore hint at a liberalization-enhancing effect of high electricity VAT rates. However, this result would only be in line with our notion that ministry officials and regulators eager for high budgets affect vertical separation when power demand is price elastic, which is a rather rare case in reality. Whether this outcome fundamentally challenges our explanation for the relationship between taxation and unbundling, or results from either reverse causality issues (which the literature on the design of tax systems indicates not to exist) or omitted variable problems (which an additional estimation indicates to exist) cannot be ascertained, though.

The partially contradictory findings rather reveal that this paper can only be seen as a first step in the analysis of how the interest of regulators in high institutional budgets might hamper or foster liberalization. Examining the potential effect of further taxes, broadening the sample (especially the smaller one we used in the VAT rate regressions due to data restrictions) or identifying and applying appropriate instruments for the tax rates to fully exclude possible endogeneity problems could be meaningful extensions that have to be left for future research. 


\section{Appendix}

Table 6: Summary Statistics

\begin{tabular}{|c|c|c|c|c|c|}
\hline Variable & Obs. & Mean & Std. Dev. & Min. & Max. \\
\hline \multicolumn{6}{|l|}{ Main Variables } \\
\hline vi & 682 & 4.137 & 2.214 & 0.00 & 6.00 \\
\hline CITrate & 682 & 37.47 & 9.856 & 12.50 & 61.80 \\
\hline elecVATrate & 491 & 12.82 & 7.384 & 0.00 & 25.00 \\
\hline \multicolumn{6}{|c|}{ Controls (Basic Regressions) } \\
\hline totaltaxrev $_{t-1}$ & 588 & 1749723 & 1330000 & 771 & 186000000 \\
\hline totalgovdebt $_{t-1}$ & 588 & 434829 & 984176 & 293.3 & 7284065 \\
\hline GDPgrowth $_{t-1}$ & 588 & 2.818 & 2.367 & -11.89 & 11.46 \\
\hline energysupGDP & 588 & .1890 & .0623 & .0900 & .4500 \\
\hline TIcor & 557 & 7.174 & 1.985 & 1.870 & 10.00 \\
\hline ideopotr & 470 & 2.911 & .8885 & 1 & 4 \\
\hline EUdum & 470 & .5830 & .4936 & 0 & 1 \\
\hline \multicolumn{6}{|c|}{ Controls (Robustness Checks) } \\
\hline taxrevGDP ${ }_{t-1}$ & 588 & 35.52 & 8.203 & 14.35 & 52.23 \\
\hline govdebtGDP $_{t-1}$ & 588 & 48.38 & 28.66 & .8210 & 164.3 \\
\hline GDPcapgrowth $_{t-1}$ & 588 & 2.200 & 2.340 & -11.89 & 10.35 \\
\hline energysupcap & 588 & 4.268 & 2.013 & 1.000 & 15.74 \\
\hline ideobjor & 438 & .2697 & .3388 & -.5167 & 1.000 \\
\hline energysupGDP ${ }_{t-1}$ & 469 & .1860 & .0623 & .1000 & .4000 \\
\hline TIcor $_{t-1}$ & 469 & 7.762 & 1.484 & 2.990 & 10.00 \\
\hline energysupcap $_{t-1}$ & 437 & 4.333 & 1.824 & 1.000 & 11.40 \\
\hline
\end{tabular}


Table 7: Robustness Checks

\begin{tabular}{|c|c|c|c|c|}
\hline & (1) & $(2)$ & (3) & (4) \\
\hline \multirow[t]{2}{*}{ CITrate } & $.0346^{* * *}$ & $.0571^{* *}$ & $.0334^{* * *}$ & $.0634^{*}$ \\
\hline & $(0.009)$ & $(0.028)$ & $(0.011)$ & $(0.034)$ \\
\hline \multirow[t]{2}{*}{ totaltaxrev $_{t-1}$} & $-1.3 \mathrm{e}-08$ & $4.4 \mathrm{e}-06^{* * *}$ & & \\
\hline & $(0.000)$ & $(0.000)$ & & \\
\hline \multirow[t]{2}{*}{$\operatorname{taxrevGDP}_{t-1}$} & & & -.0037 & -.0499 \\
\hline & & & $(0.033)$ & $(0.092)$ \\
\hline \multirow{2}{*}{ totalgovdebt $_{t-1}$} & $3.9 \mathrm{e}-07^{* * *}$ & $-2.1 \mathrm{e}-06^{* * *}$ & & \\
\hline & $(0.000)$ & $(0.000)$ & & \\
\hline \multirow[t]{2}{*}{ govdebtGDP $_{t-1}$} & & & $.0075^{*}$ & -.0071 \\
\hline & & & $(0.005)$ & $(0.019)$ \\
\hline \multirow[t]{2}{*}{ GDPgrowth $_{t-1}$} & -.0348 & -.0182 & & \\
\hline & $(0.027)$ & $(0.087)$ & & \\
\hline \multirow[t]{2}{*}{ GDPcapgrowth $_{t-1}$} & & & -.0172 & -.0183 \\
\hline & & & $(0.028)$ & $(0.075)$ \\
\hline \multirow[t]{2}{*}{ energysupGDP $_{t-1}$} & $-18.68^{* * *}$ & $-73.79^{* * *}$ & & \\
\hline & $(3.564)$ & $(12.684)$ & & \\
\hline \multirow[t]{2}{*}{$\operatorname{energysupcap}_{t-1}$} & & & $-.4398^{*}$ & -1.148 \\
\hline & & & $(0.250)$ & $(0.901)$ \\
\hline \multirow[t]{2}{*}{ TIcor $_{t-1}$} & -.1470 & $-.7079^{* *}$ & -.0933 & -.0818 \\
\hline & $(0.095)$ & $(0.287)$ & $(0.094)$ & $(0.239)$ \\
\hline \multirow[t]{2}{*}{ ideopotr } & $.2425^{* * *}$ & $.6788^{* * *}$ & & \\
\hline & $(0.060)$ & $(0.169)$ & & \\
\hline \multirow[t]{2}{*}{ ideobjor } & & & -.2876 & -.3132 \\
\hline & & & $(0.202)$ & $(0.692)$ \\
\hline \multirow[t]{2}{*}{ EUdum } & -.2405 & $-1.284^{*}$ & $-.9833^{* * *}$ & $-1.521^{* *}$ \\
\hline & $(0.271)$ & $(0.766)$ & $(0.280)$ & $(0.723)$ \\
\hline \multirow[t]{2}{*}{ constant } & $8.674^{* * *}$ & & $6.233^{* * *}$ & \\
\hline & $(1.092)$ & & $(1.489)$ & \\
\hline country dummies & yes & yes & yes & yes \\
\hline year dummies & yes & yes & yes & yes \\
\hline$R^{2}$ & .8304 & & .7899 & \\
\hline Pseudo $-R^{2}$ & & .6463 & & .5825 \\
\hline$N$ & 469 & 469 & 437 & 437 \\
\hline
\end{tabular}

Note: Columns (1) and (3) show estimation results of standard linear OLS estimations, columns (2) and (4) those of ordered logit regressions. Dependent variable is the vertical integration sub-indicator for the electricity sector as described in Conway and Nicoletti (2006). Robust standard errors in parentheses. $* * * / * * / *$ denotes statistical significance at the $1 \% / 5 \% / 10 \%$ level. 
Table 7A: Changes in Expected VI Subindicator Values

\begin{tabular}{lllllll}
\hline & \multicolumn{7}{c}{ corporate income tax rate base level $(\overline{\text { CITrate }})$} \\
& $10 \%$ & $20 \%$ & $30 \%$ & $40 \%$ & $50 \%$ & $60 \%$ \\
\hline$\Delta E(v i)$ (based on col. (2) of Tab. 7) & .0166 & .0165 & .0162 & .0157 & .0150 & .0141 \\
$\Delta E(v i)$ (based on col. (4) of Tab. 7) & .0215 & .0209 & .0202 & .0192 & .0179 & .0163 \\
\hline \hline
\end{tabular}

Note: Table 7A reports changes in the conditional expected values of the vertical integration sub-indicator for the electricity sector induced by a one percentage point increase in the corporate income tax rate, start-

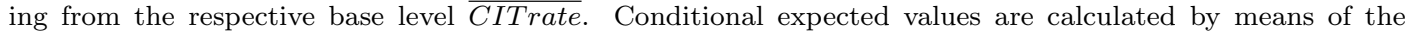
average predicted probabilities based on the ordered logit estimates reported in column (2) and column (4), respectively, of Table 7 .

TABle 8: Robustness Checks

\begin{tabular}{|c|c|c|c|}
\hline & (1) & $(2)$ & (3) \\
\hline \multirow[t]{2}{*}{ CITrate } & $.0539^{* * *}$ & & $.0520^{* * *}$ \\
\hline & $(0.011)$ & & $(0.011)$ \\
\hline \multirow[t]{2}{*}{ elecVATrate } & & $-.0437^{* *}$ & -.0076 \\
\hline & & $(0.018)$ & $(0.018)$ \\
\hline \multirow[t]{2}{*}{ totaltaxrev $_{t-1}$} & $7.7 \mathrm{e}-08$ & $4.7 \mathrm{e}-07$ & $1.4 \mathrm{e}-07$ \\
\hline & $(0.000)$ & $(0.000)$ & $(0.000)$ \\
\hline \multirow[t]{2}{*}{ totalgovdebt $_{t-1}$} & $4.8 \mathrm{e}-07^{* * *}$ & $4.9 \mathrm{e}-07^{* * *}$ & $4.8 \mathrm{e}-07^{* * *}$ \\
\hline & $(0.000)$ & $(0.000)$ & $(0.000)$ \\
\hline \multirow[t]{2}{*}{ GDPgrowth $_{t-1}$} & .0337 & .0074 & .0322 \\
\hline & $(0.035)$ & $(0.037)$ & $(0.035)$ \\
\hline \multirow[t]{2}{*}{ energysupGDP } & $-16.33^{* * *}$ & $-15.71^{* * *}$ & $-16.57^{* * *}$ \\
\hline & $(4.920)$ & $(5.091)$ & $(4.960)$ \\
\hline \multirow[t]{2}{*}{ TIcor } & $-.4342^{* * *}$ & $-.3580^{* * *}$ & $-.4280^{* * *}$ \\
\hline & $(0.117)$ & $(0.123)$ & $(0.117)$ \\
\hline \multirow[t]{2}{*}{ ideopotr } & $.2724^{* * *}$ & $.2830^{* * *}$ & $.2711^{* * *}$ \\
\hline & $(0.075)$ & $(0.079)$ & $(0.075)$ \\
\hline \multirow[t]{2}{*}{ EUdum } & -.1609 & -.1679 & -.1316 \\
\hline & $(0.371)$ & $(0.370)$ & $(0,385)$ \\
\hline \multirow[t]{2}{*}{ constant } & $8.469^{* * *}$ & $10.50^{* * *}$ & $8.617^{* * *}$ \\
\hline & $(1.267)$ & $(1.432)$ & $(1.327)$ \\
\hline country dummies & yes & yes & yes \\
\hline year dummies & yes & yes & yes \\
\hline$R^{2}$ & .8658 & .8563 & .8658 \\
\hline$N$ & 326 & 326 & 326 \\
\hline
\end{tabular}

Note: Columns (1) to (3) show estimation results of standard linear OLS estimations. Dependent variable is the vertical integration sub-indicator for the electricity sector as described in Conway and Nicoletti (2006). Robust standard errors in parentheses. $* * * / * *$ denotes statistical significance at the $1 \% / 5 \%$ level. 
Table 9: Robustness Checks

\begin{tabular}{|c|c|c|c|c|}
\hline & (1) & $(2)$ & (3) & (4) \\
\hline \multirow[t]{2}{*}{ elecVATrate } & $-.0443^{* *}$ & $-.1855^{* * *}$ & $-.0480^{* *}$ & $-.1951^{* * *}$ \\
\hline & $(0.018)$ & $(0.055)$ & $(0.019)$ & $(0.062)$ \\
\hline \multirow{2}{*}{ totaltaxrev $_{t-1}$} & $4.1 \mathrm{e}-07$ & $7.1 \mathrm{e}-06^{* * *}$ & & \\
\hline & $(0.000)$ & $(0.000)$ & & \\
\hline \multirow[t]{2}{*}{ taxrevGDP $_{t-1}$} & & & .0318 & .0714 \\
\hline & & & $(0.042)$ & $(0.136)$ \\
\hline \multirow[t]{2}{*}{ totalgovdebt $_{t-1}$} & $5.5 \mathrm{e}-07^{* * *}$ & $-1.1 \mathrm{e}-06$ & & \\
\hline & $(0.000)$ & $(0.000)$ & & \\
\hline \multirow[t]{2}{*}{$\operatorname{govdebtGDP}_{t-1}$} & & & .0062 & -.0304 \\
\hline & & & $(0.006)$ & $(0.023)$ \\
\hline \multirow[t]{2}{*}{ GDPgrowth $_{t-1}$} & .0065 & -.0096 & & \\
\hline & $(0.036)$ & $(0.109)$ & & \\
\hline \multirow[t]{2}{*}{ GDPcapgrowth $_{t-1}$} & & & .0056 & .0252 \\
\hline & & & $(0.032)$ & $(0.120)$ \\
\hline \multirow[t]{2}{*}{ energysupGDP $_{t-1}$} & $-19.42^{* * *}$ & $-78.06^{* * *}$ & & \\
\hline & $(4.495)$ & $(15.83)$ & & \\
\hline \multirow[t]{2}{*}{ energysupcap $_{t-1}$} & & & -.0293 & -.9266 \\
\hline & & & $(0.336)$ & $(1.194)$ \\
\hline \multirow[t]{2}{*}{ TIcor $_{t-1}$} & $-.2472^{*}$ & $-.9343^{* *}$ & $-.3245^{* *}$ & $-.9940^{*}$ \\
\hline & $(0.127)$ & $(0.440)$ & $(0.137)$ & $(0.519)$ \\
\hline \multirow[t]{2}{*}{ ideopotr } & $.3134^{* * *}$ & $.6941^{* * *}$ & & \\
\hline & $(0.079)$ & $(0.216)$ & & \\
\hline \multirow[t]{2}{*}{ ideobjor } & & & $-.7372^{* * *}$ & $-2.048^{* *}$ \\
\hline & & & $(0.255)$ & $(0.830)$ \\
\hline \multirow[t]{2}{*}{ EUdum } & -.0729 & -1.245 & $-.7433^{*}$ & -.8345 \\
\hline & $(0.371)$ & $(1.211)$ & $(0.419)$ & $(1.050)$ \\
\hline \multirow[t]{2}{*}{ constant } & $10.69^{* * *}$ & & $5.902^{* * *}$ & \\
\hline & $(1.467)$ & & $(2.054)$ & \\
\hline country dummies & yes & yes & yes & yes \\
\hline year dummies & yes & yes & yes & yes \\
\hline$R^{2}$ & .8558 & & .8411 & \\
\hline Pseudo- $R^{2}$ & & .6713 & & .6561 \\
\hline$N$ & 327 & 327 & 288 & 288 \\
\hline
\end{tabular}

Note: Columns (1) and (3) show estimation results of standard linear OLS estimations, columns (2) and (4) those of ordered logit regressions. Dependent variable is the vertical integration sub-indicator for the electricity sector as described in Conway and Nicoletti (2006). Robust standard errors in parentheses. $* * * / * * / *$ denotes statistical significance at the $1 \% / 5 \% / 10 \%$ level. 
Table 9A: Changes in Expected VI Subindicator Values

\begin{tabular}{lcccc}
\hline & \multicolumn{3}{c}{ electricity VAT rate base level (elecV ATrate $)$} \\
& $5 \%$ & $10 \%$ & $15 \%$ & $20 \%$ \\
\hline$\Delta E(v i)$ (based on col. (2) of Tab. 9) & -.0403 & -.0450 & -.0501 & -.0541 \\
$\Delta E(v i)$ (based on col. (4) of Tab. 9) & -.0411 & -.0467 & -.0522 & -.0566 \\
\hline \hline
\end{tabular}

Note: Table 9A reports changes in the conditional expected values of the vertical integration subindicator for the electricity sector induced by a one percentage point increase in the electricity VAT rate, starting from the respective base level elecVATrate. Conditional expected values are calculated by means of the average predicted probabilities based on the ordered logit estimates reported in column (2) and column (4), respectively, of Table 9. 


\section{References}

Ades, A. and Di Tella, R. (1997a): The New Economics of Corruption: A Survey and Some New Results, Political Studies, 45(3), 496-515.

Ades, A. and Di Tella, R. (1997b): National Champions and Corruption: Some Unpleasant Interventionist Arithmetic, Economic Journal, 107(443), 1023-1042.

Ades, A. and Di Tella, R. (1999): Rents, Competition, and Corruption, American Economic Review, 89(4), 982-993.

Agrell, P. J. and Gautier, A. (2010): A Theory of Soft Capture, CORE Discussion Paper 2010/85, Center for Operations Research and Econometrics, Catholic University of Louvain, December 2010.

ASAP (2008): The American State Administrators Project - 2008 Reports and Tables, available online: www.auburn.edu/outreach/cgs/ASAP/tables2008.pdf, October 2013.

Bağdigen, M. (2003): An Analysis of Bureaucratic Attitudes towards Budgeting in Turkey, in: Sağbaş, I. and Bağdigen, M. (eds.): Local Government Finance in Turkey, Afyon Kocatepe University Publication No. 57, Afyonkarahisar, Turkey: Z Ajans Afyon, 83-106.

Bean, C. R. (1998): The Interaction of Aggregate-Demand Policies and Labor Market Reform, Swedish Economic Policy Review, 5(2), 353-382.

Benoit, K. and Laver, M. (2006): Party Policy in Modern Democracies, London, UK and New York, NY, USA: Routledge.

Bird, R. M. and Wilkie, J. S. (2012): Designing Tax Policy: Constraints and Objectives in an Open Economy, International Center for Public Policy Working Paper 12-24, International Center for Public Policy, Andrew Young School of Policy Studies, Georgia State University, April 2012.

Bjørnskov, C. (2008): Political Ideology and the Structure of National Accounts in the Nordic Countries 1950-2004, Aarhus University Working Paper, Department of Economics and Business, Aarhus University, March 2008. 
Blais, A. and Dion, S. (1990): Are Bureaucrats Budget Maximizers? The Niskanen Model \& Its Critics, Polity, 22(4), 655-674.

Blázquez, L., Boogen, N. and Filippini, M. (2012): Residental Electricity Demand for Spain: New Empirical Evidence Using Aggregated Data, CEPE Working Paper No. 82, Centre for Energy Policy and Economics, Swiss Federal Institutes of Technology Zurich, February 2012.

Bowling, C. J., Cho, C.-L. and Wright, D. S. (2004): Establishing a Continuum from Minimizing to Maximizing Bureaucrats: State Agency Head Preferences for Governmental Expansion - A Typology of Administrator Growth Postures, 1964-98, Public Administration Review, 64(4), 489-499.

Brys, B., Matthews, S. and Owens, J. (2011): Tax Reform Trends in OECD Countries, OECD Taxation Working Papers No. 1, Paris, France: OECD Publishing.

Cameron, A. C. and Trivedi, P. K. (2005): Microeconometrics - Methods and Applications, New York, NY, USA: Cambridge University Press.

CEER (2005): CEER Regulatory Benchmark Report 2005, Ref: C05-IEB-08-03, 6 December 2005, Brussels.

Conway, P. and Nicoletti, G. (2006): Product Market Regulation in the Non-Manufacturing Sectors of OECD Countries: Measurement and Highlights, OECD Economics Department Working Papers, No. 530, Paris, France: OECD Publishing.

Dicembrino, C. and Trovato, G. (2013): Structural Breaks, Price and Income Elasticity and Forecast of the Monthly Italian Electricity Demand - Paper Presented at the 10th International Conference on the European Energy Market (EEM 13), Royal Institute of Technology (KTH) Stockholm, 27 - 31 May 2013, mimeo.

Döhler, M. (2002): Institutional Choice and Bureaucratic Autonomy in Germany, West European Politics, 25(1), 101-124.

Domanico, F. (2007): Concentration in the European Electricity Industry: The Internal Market as Solution?, Energy Policy, 35(10), 5064-5076.

Downs, A. (1967): Inside Bureaucracy, Boston, MA, USA: Little, Brown and Company. 
Drazen, A. and Easterly, W. (2001): Do Crises Induce Reform? Simple Empirical Tests of Conventional Wisdom, Economics and Politics, 13(2), 129-157.

Drazen, A. and Grilli, V. (1993): The Benefit of Crises for Economic Reform, American Economic Review, 83(3), 598-607.

Dunleavy, P. (1985): Budgets and the Grwoth of the State: Reconstructing an Instrumental Model, British Journal of Political Science, 15(3), 299-328.

Emerson, P. M. (2006): Corruption, Competition and Democracy, Journal of Development Economics, 81(1), 193-212.

European Commission (2007): DG Competition Report on Energy Sector Inquiry - 10 January 2007, SEC(2006) 1724, Brussels.

European Communities (1996): Directive 96/92/EC of the European Parliament and of the Council of 19 December 1996 Concerning Common Rules for the Internal Market in Electricity, Official Journal of the European Communities L27, 30 January 1997, 20-29.

European Union (2003): Directive 2003/54/EC of the European Parliament and of the Council of 26 June 2003 Concerning Common Rules for the Internal Market in Electricity and Repealing Directive 96/92/EC, Official Journal of the European Union L176, 15 July 2003, 37-55.

European Union (2009): Directive 2009/72/EC of the European Parliament and of the Council of 13 July 2009 Concerning Common Rules for the Internal Market in Electricity and Repealing Directive 2003/54/EC, Official Journal of the European Union L211, 14 August 2009, 55-93.

European Union (2011): Europe - Countries, available online: http://europa.eu/abouteu/countries/index_en.htm, March 2011.

Gilardi, F. (2008): Delegation in the Regulatory State - Independent Regulatory Agencies in Western Europe, Cheltenham, UK and Northampton, MA, USA: Edward Elgar.

Glachant, J.-M. and Léfêque, F. (2009): The Electricity Internal Market in the European Union: What to Do Next?, in: Glachant, J.-M. and Léfêque, F. (eds.), Electricity Reform in 
Europe - Towards a Single Energy Market, Cheltenham, UK and Northampton, MA, USA: Edward Elgar, 35-64.

Grandjean, B. D. (1981): History and Career in a Bureaucratic Labor Market, American Journal of Sociology, 86(5), 1057-1092.

Hanretty, C. and Koop, C. (2009): Comparing Regulatory Agencies. Report on the Results of a Worldwide Survey, EUI Working Paper, RSCAS 2009/63, Robert Schuman Centre for Advanced Studies, European University Institute, December 2009.

Hood, C., Huby, M. and Dunsire, A. (1984): Bureaucrats and Budgeting Benefits: How Do British Central Government Departments Measure Up?, Journal of Public Policy, 4(3), 163179.

Jacobsen, D. I. (2006): Public Sector Growth: Comparing Politicians' and Administrators' Spending Preferences, Public Administration, 84(1), 185-204.

James, S. and Edwards, A. (2008): Developing Tax Policy in a Complex and Changing World, Economic Analysis \& Policy, 38(1), 35-53.

Johannsen, K. S., Pedersen, L. H. and Sørensen, E. M. (2004): Independent Regulatory Authorities - A Comparative Study of European Energy Regulators, AKF Forlaget, April 2004.

Karan, M. B. and Kazdağli, H. (2011): The Development of Energy Markets in Europe, in: Dorsman, A., Westerman, W., Karan, M. B. and Özgür, A. (eds.), Financial Aspects in Energy - A European Perspective, Berlin and Heidelberg, Germany: Springer, 11-32.

Katz, M. L. and Rosen, H. S. (1998): Microeconomics, 3rd ed., Boston, MA, USA et al.: Irwin/McGraw-Hill.

Krueger, A. B. (1988): The Determinants of Queues for Federal Jobs, Industrial and Labor Relations Review, 41(4), 567-581.

Krueger, A. O. (1993): Virtuous and Vicious Circles in Economic Development, American Economic Review, 83(2), 351-355. 
Lambsdorff, J. (2006): The Methodology of the Corruption Perceptions Index 2006, Transparency International and University of Passau, October 2006.

Lauth, T. P. (1986): The Executive Budget in Georgia, State and Local Government Review, $18(2), 56-64$.

LeLoup, L. T. and Moreland, W. B. (1978): Agency Strategies and Executive Review: The Hidden Politics of Budgeting, Public Administration Review, 38(3), 232-239.

Levi-Faur, D. (2004): One the "Net Impact" of Europeanization - The EU's Telecoms and Electricity Regimes Between the Global and the National, Comparative Political Studies, 37(1), $3-29$.

Madlener, R., Bernstein, R. and Gonzlez, M. Á. A. (2011): Econometric Estimation of Energy Demand Elasticities, E.ON Energy Research Center Series, Volume 3, Issue 8, E.ON Energy Research Center, RWTH Aachen.

Maggetti, M. (2007): De Facto Independence after Delegation: A Fuzzy-Set Analysis, Regulation \& Governance, 1(4), 271-294.

Majone, G. (1996): The Rise of Statutory Regulation in Europe, in: Majone, G. (ed.), Regulating Europe, London, UK and New York, NY, USA: Routledge, 47-60.

Mauro, P. (1996): The Effects of Corruption on Growth, Investment, and Government Expenditure, IMF Working Paper WP/96/98, International Monetary Fund, Policy Development and Review Department, September 1996.

Migué, J.-L. and Bélanger, G. (1974): Toward a General Theory of Managerial Discretion, Public Choice, 17(1), 27-47.

Moe, T. M. (1989): The Politics of Bureaucratic Structure, in: Chubb, J. E. and Peterson, P. E. (eds.), Can the Government Govern?, Washington, D.C., USA: Brookings Institution Press, 267-329.

Moe, T. M. (1990): Political Institutions: The Neglected Side of the Story, Journal of Law, Economics, and Organization, 6(Special Issue), 213-253. 
Myles, G. D. (1995): Public Economics, Cambridge, UK: Cambridge University Press.

Narayan, P. K., Smyth, R. and Prasad, A. (2007): Electric Consumption in G7 Countries: A Panel Cointegration Analysis of Residental Demand Elasticities, Energy Policy, 35(9), 4485-4494.

Newbery, D. (2009): Refining Market Design, in: Glachant, J.-M. and Léfêque, F. (eds.), Electricity Reform in Europe - Towards a Single Energy Market, Cheltenham, UK and Northampton, MA, USA: Edward Elgar, 35-64.

Niskanen, W. A. (1968): Nonmarket Decision Making - The Peculiar Economics of Bureaucracy, American Economic Review, 58(2), 293-305.

Niskanen, W. A. (1975): Bureaucrats and Politicians, Journal of Law and Economics, 18(3), 617-643.

OECD (2001): Restructuring Public Utilities for Competition, Paris, France: OECD Publishing.

OECD (2010a): OECD.Stat, available online: http://www.oecd-ilibrary.org/economics/data/ oecd-stat_data-00285-en, November 2010.

OECD (2010b): OECD Factbook 2010 - Economic, Environmental and Social Statistics, Paris, France: OECD Publishing.

OECD (2011a): Product Market Regulation Database, available online: http://www.oecd.org/ economy/pmr, March 2011.

OECD (2011b): OECD Tax Database, available online: http://www.oecd.org/ctp/ taxdatabase, March 2011.

OECD/IEA (2001): Regulatory Institutions in Liberalised Electricity Markets, Paris, France: IEA Publications.

Owens, J. (2006): Fundamental Tax Reform: An International Perspective, National Tax Journal, 59(1), 131-164. 
Peters, B. G. (1978): The Politics of Bureaucracy - A Comparative Perspective, New York, NY, USA and London, GB: Longman.

Pitlik, H. (2007): A Race to Liberalization? Diffusion of Economic Policy Reform among OECD-Economies, Public Choice, 132(1-2), 159-178.

Pitlik, H. (2008): The Impact of Growth Performance and Political Regime Type on Economic Policy Liberalization, Kyklos, 61(2), 258-278.

Pitlik, H. and Wirth, S. (2003): Do Crises Promote the Extent of Economic Liberalization?: An Empirical Test, European Journal of Political Economy, 19(3), 565-581.

Pollitt, M. (2008): The Arguments for and against Ownership Unbundling of Energy Transmission Networks, Energy Policy, 36(2), 704-713.

Potrafke, N. (2009): Did Globalization Restrict Partisan Politics? An Empirical Evaluation of Social Expenditures in a Panel of OECD Countries, Public Choice, 140(1-2), 105-124.

Potrafke, N. (2010): Does Government Ideology Influence Deregulation of Product Markets? Empirical Evidence from OECD Countries, Public Choice, 143(1-2), 135-155.

Rodrik, D. (1996): Understanding Economic Policy Reform, Journal of Economic Literature, $34(1), 9-41$.

Rourke, F. E. (1984): Bureaucracy, Politics, and Public Policy, 3rd Edition, Boston, MA, USA and Toronto, Canada: Little, Brown and Company.

Ryu, J. E., Bowling, C. J., Cho, C.-L. and Wright, D.S. (2007): Effects of Administrators' Aspirations, Political Principals' Priorities, and Interest Groups' Influence on State Agency Budget Requests, Public Budgeting \& Finance, 27(2), 22-49.

Schneider, V. and Jäger, A. (2003): The Privatization of Infrastructures in the Theory of the State: An Empirical Overview and a Discussion of Competing Theoretical Explanations, in: Wubben, E. F. M. and Hulsink, W. (eds.), On Creating Competition and Strategic Restructuring - Regulatory Reform in Public Utilities, Cheltenham, UK and Northampton, MA, USA: Edward Elgar, 101-137. 
Sharkansky, I. (1965): Four Agencies and an Appropriations Subcommitee: A Comparative Study of Budget Strategies, Midwest Journal of Political Science, 9(3), 254-281.

Sharkansky, I. (1968): Agency Requests, Gubernatorial Support and Budget Success in State Legislatures, American Political Science Review, 62(4), 1220-1231.

Sigelman, L. (1986): The Bureaucrat as Budget Maximizer: An Assumption Examined, Public Budgeting \& Finance, 6(1), 50-59.

Smith, W. (1997): Utility Regulators - The Independence Debate, Public Policy for the Private Sector, Note No. 127 (October), Washington, D.C.: The World Bank Group - Finance, Private Sector and Infrastructure Network.

Stiglitz, J. E. (2000): Economics of the Public Sector, 3rd ed., New York, NY, USA and London, UK: W.W. Norton \& Company.

Tanzi, V. (1994): Corruption, Governmental Activities, and Markets, IMF Working Paper WP/94/99, International Monetary Fund, Fiscal Affairs Department, August 1994.

Thatcher, M. (2002a): Delegation to Independent Regulatory Agencies: Pressures, Functions and Contextual Mediation, West European Politics, 25(1), 125-147.

Thatcher, M. (2002b): Regulation after Delegation: Independent Regulatory Agencies in Europe, Journal of European Public Policy, 9(6), 954-972.

Thatcher, M. and Stone Sweet, A. (2002): Theory and Practice of Delegation to NonMajoritarian Institutions, West European Politics, Vol. 25(1), 1-22.

Thompson, J. A. (1987): Agency Requests, Gubernatorial Support and Budget Success in State Legislatures Revisited, Journal of Politics, 49(3), 756-779.

Transparency International (2012): Corruption Perceptions Index, available online: http://www.transparency.org/research/cpi, May 2012.

Treisman, D. (2000): The Causes of Corruption: A Cross-National Study, Journal of Public Economics, 76(3), 399-457. 
Tullock, G., Seldon, A. and Brady, G. L. (2002): Government Failure - A Primer in Public Choice, Washington, D.C., USA: Cato Institute.

van Koten, S. and Ortmann, A. (2008): The Unbundling Regime for Electricity Utilities in the EU: A Case of Legislative and Regulatory Capture?, Energy Economics, 30(6), 3128-3140.

Varian, H. R. (2010): Intermediate Microeconomics - A Modern Approach, 8th Edition, New York, NY, USA and London, UK: W. W. Norton \& Company.

Venetoklis, T. and Kiander, J. (2006): Spending Preferences of Public Sector Officials: Survey Evidence from Finland, Public Budgeting \& Finance, 26(2), 20-44.

Viscusi, W. K., Harrington, J. E. and Vernon, J. M. (2005): Economics of Regulation and Antitrust, 4th Edition, Cambridge, MA, USA: MIT Press.

Wildavsky, A. and Caiden, N. (2004): The New Politics of the Budgetary Process, 5th Edition, New York, NY, USA et al.: Pearson Longman.

Wooldridge, J. M. (2002): Econometric Analysis of Cross Section and Panel Data, Cambridge, MA, USA and London, UK: MIT Press.

World Bank (2011): World Development Indicators, available online: http:// data.worldbank.org/data-catalog/world-development-indicators, December 2011. 